\title{
METODE PENDIDIKAN KELUARGA DALAM PERSPEKTIF ISLAM
}

\author{
Sutinah \\ E-mail: staimsyogyakarta@yahoo.co.id \\ Dosen Program Studi Pendidikan Agama Islam \\ Sekolah Tinggi Agama Islam Masjid Syuhada Yogyakarta
}

\section{Abstrak}

Keluarga adalah institusi pertama dan terkecil yang ada dalam suatu masyarakat dimana terjadi hubungan-hubungan antar anggota keluarga atau hubungan antar keluarga dengan keluarga lainnya dalam suatu masyarakat. Pendidikan keluarga adalah sebuah upaya yang dilakukan oleh orang tua secara terencana untuk mengembangkan akal, perasaan dan perilaku anak-anak yang didasarkan atas ajaran Islam, sehingga terbentuk anak saleh-salehah yang dapat mewujudkan tujuan agama Islam dalam seluruh segi kehidupan manusia. Tujuan pendidikan keluarga adalah agar anak mampu berkembang secara maksimal yang meliputi seluruh aspek perkembangan anak yaitu jasmani, ruhani dan akal. Selain itu juga untuk membantu sekolah atau lembaga pendidikan lainnya dalam mengembangkan kepribadian anak didik. Adapun metode pendidikan keluarga menurut Islam adalah metode keteladanan, metode kisah, metode kasih sayang, metode dengan memberikan ganjaran, metode nasehat, metode dialog dan metode pembiasaan.

\section{Kata Kunci: Metode, Pendidikan, Keluarga}

\section{Abstract}

Family is the first and smallest institution that exists in a society where relationships between family members occur or relationships between families with other families in a community. Family education is an effort made by parents in a planned manner to develop the mind, feelings and behavior of children based on Islamic teachings, so that a saleh and saleha child who can realize the goals of Islam in all aspects of human life is formed. The purpose of family education is to make the children develop optimally which covers all aspects of child development, namely physical, spiritual and reason. In addition, it is also to help schools or other educational institutions in developing students' personalities. The method of family education according to Islam for examples are story methods, methods of affection, methods of giving rewards, methods of advice, dialogue and habituation methods.

\section{Keywords: Method, Education, Family}




\section{A. Pendahuluan}

Keluarga adalah unit terkecil masyarakat yang mempunyai peranan dan tanggungjawab penting dalam membentuk anggota keluarga agar menjadi generasi masa depan yang baik dan siap menghadapi dinamika perubahan yang semakin variatif.

Sekalipun tanggung jawab utama pendidikan anak-anak terletak ditangan orang tua, namun karena kebutuhan bangsa akan tenaga profesional dalam berbagai bidang, maka mengharuskan orang tua mengalihkan sebagian tanggung jawab dan tugas mendidik anak-anak kepada lembaga pendidikan tertentu. Namun demikin, tidak berarti tanggung jawab dan tugas mendidik tersebut terlepas sama sekali dari orang tua. Apabila lembaga pendidikan lebih pada aspek mengajarkan sejumlah pengetahuan untuk membentuk intelektual anak, maka orang tua secara bersama-sama dengana lembaga pendidikan mendidik akhlak dan pengamalan agama kepada anak-anak.. Untuk menuntun orang tua dalam menjalankan tanggungjawab dan tugas tersebut, sebagai pendidik utama, maka dalam Islam dikenal adanya konsep pendidikan keluarga. Tulisan ini akan memaparkan pengertian keluarga, pendidika keluarga, dan macam-macam metode pendidikan keluarga dalam perspektif Islam.

\section{B. PEMBAHASAN}

\section{Pengertian Keluarga}

Sebagai unit terkecil dalam masyarakat, keluarga terbentuk atas dasar sukarela dan cinta kasih yang azasi antara suami dan istri. Berdasarkan asas cinta yang azasi ini, kemudian lahirlah anak sebagai generasi penerus. Dengan perasaan cinta kasih dan pengabdian yang luhur itu pulalah keluarga membina kehidupan anak (Tim Dosen, 1981). Menurut Chaplin (1973: 180) keluarga adalah sekelompok orang yang dihubungkan oleh perkawinan atau darah yang secara khusus terdiri dari 
seorang ayah, ibu dan anak-anak. Dengan perkataan lain bahwa keluarga adalah perkumpulan halal seorang laki-laki dengan seorang perempuan yang secara terus menerus dimana yang satu merasa tenteram karena adanya yang lain sesuai dengan ketentuan agama dan norma-norma masyarakat (Langgulung,1986: 346). Keluarga adalah kesatuan fungsi yang terdiri dari suami, istri dan anak-anak yang diikat oleh ikatan darah dan tujuan bersama (Sarhani, 1978: 183). Yang dimaksud keluarga disini adalah hanya keluarga batih "Nuclear famil ", (Horton, 1987: 286). Keluarga menurut konsep Islam adalah terdiri dari ayah (zauj), istri (zaujah), anak laki-laki (ibn) atau anak perempuan (bint). Kerabat atau sanak famili adalah keluarga terdekat.

Keluarga secara sosiologis adalah kesatuan kemasyarakatan berdasarkan hubungan perkawinan atau pertalian darah. Dalam menentukan batas-batas hubungan keluarga, terdapat berbagai perbedaan atas dasar jenis bangsa, kebudayaan atau tata kemasyarakatan. Berdasarkan hal tersebut dapat dibedakan atas; Keluarga inti atau keluarga batih yang terdiri dari Bapak, Ibu dan anak-anak dimana terjalin hubungan kekeluargaan atau beberapa sanak saudara dengan anak-anaknya yang berumah tangga. Susunan kekeluargaan bertalian dengan hakikat kedudukan perkawinan dalam tata masyarakat yang merupakan masalah yang sangat penting artinya dalam hal hukum waris (Ensiklopedi Indonesia Edisi Khusus, 1998: 1728).

Menurut Vembiarto (1993: 53) inti pengertian keluarga itu adalah: Pertama, Keluarga merupakan kelompok sosial terkecil yang umumnya terdiri dari ayah, ibu dan anak. Kedua, Hubungan sosial diantara anggota keluarga relatif tetap, yang 
didasarkan atas ikatan perkawinan, darah atau pengangkatan. Ketiga, Hubungan antara anggota keluarga dijiwai suasana afeksi dan rasa tanggung jawab dan. Keempat, Fungsi keluarga adalah memelihara, merawat dan melindungi anak dalam rangka sosialisasi agar mereka mampu mengendalikan diri serta mempunyai jiwa sosial.

Di dalam keluarga itu terdapat unsur-unsur yang saling menguatkan yaitu: Pertama, Perasaan saling mencintai, menghargai dan saling bersaing secara sehat. Kedua, Bertujuan sebagai tempat proses sosialisasi, serta menjamin ketenteraman jiwa anggota keluarga. Ketiga, Terdapat kaidah-kaidah tertentu yang mengatur antara anggota keluarganya maupun pihak lain diluar keluarga. Keempat, Kekuasaan yang dimiliki orang tua merupakan salah satu dasar melakukan pengawasan proses hubungan kekeluargaan. Kelima, Adanya sangsi-sangsi positif maupun negatif yang diterapkan dalam keluarga. Keenam, Berfungsi sebagai tempat anggotanya memperoleh perlindungan bagi ketenteraman dan perkembangan jiwanya (Soekanto, 1992: 1). Oleh karena itu, keluarga menurut Soesilo (1985) merupakan tempat anak-anak belajar dan menyatakan diri sebagai makhluk sosial, memberikan dasar pembentukan perilaku, pendidikan kepada anak serta sebagai tempat anak mengharapkan dan mendapatkan pemenuhan kebutuhan kepuasan emosional, perkembangan fisik maupun psikis.

Hakikat keluarga menurut Al-Ati (1984: 41) adalah terletak pada adanya rasa saling harap antara para anggota dalam struktur keluarga itu. Keanggotaan keluarga itu terjadi oleh karena ikatan darah secara natural (natural blood ties), pernikahan atau keduanya. Dengan demikian kehadiran orang 
tua dalam suatu keluarga menjadi sangat penting, karena orang tualah yang berperan menentukan masa depan kehidupan anak.

Secara psikologis seorang anak memang memerlukan pembimbing, pembina untuk mengarahkan perkembangan jiwanya. Hal itu sejalan dengan pandangan Sabur (1986: 53) bahwa pada hakikatnya keluarga atau rumah tangga adalah tempat pertama dan utama bagi anak untuk memperoleh pembinaan mental dan pembentukan kepribadian yang kemudian ditambah dan disempurnakan melalui sekolah. Demikian pula dengan pendidikan agama harus diberikan oleh orang tua pada saat masih kanak-kanak melalui pembiasaan berakhlak dan bertingkah laku sebagaimana yang diajarkan agama. Oleh Karena itu, keluarga sebagai tempat pertama terbentuknya masyarakat tentu akan mewarnai perkembangan hidup dan cita-cita kehidupan manusia. Islam menganjurkan manusia untuk membangun keluarga sebagai institusi Islami, yakni berusaha menjadikan keluarga sebagai sumber dalam proses yang mencerminkan kehidupan yang Islami, sehingga akan terwujudlah suatu keluarga muslim yang utuh.

Menurut Eshleman (1978: 86) bahwa keluarga mengandung beberapa unsur yaitu: Pertama, Keluarga adalah institusi pertama dan terkecil yang ada dalam suatu masyarakat dimana terjadi hubungan-hubungan antar anggota keluarga atau hubungan antar keluarga dengan keluarga lainnya dalam suatu masyarakat. Kedua, Keluarga lahir sebagai akibat dari sebuah perkawinan. Ketiga, Keluarga terdiri dari orang-orang yang terikat oleh perkawinan, darah dan pengangkatan. Keempat, Anggota keluarga memiliki tempat tinggal yang sama. 
Syaiful Anam : Pendidikan Pesantren Sebagai Model Yang Ideal Dalam Pendidikan Islam

Kelima, Anggota-anggota keluarga mempunyai hak dan kewajiban timbal balik satu dengan lainnya. Keenam, Keluarga mempunyai fungsi utama, yaitu sosialisasi terutama untuk anak-anak. Sedangkan keluarga muslim adalah keluarga yang terikat dengan norma-norma Islam dan berupaya melaksanakan fungsi keluarga sesuai dengan kaedah norma tersebut. Dalam beberapa ayat Al-Qur'an dan hadis Nabi Saw dijumpai istilah keluarga, misalnya peringatan Allah kepada orang-orang yang beriman, agar memelihara diri dan keluarganya dari api neraka (Q.S.At-Tahrim: 6 /Shihab, 2003, 14: 326). Ayat ini menunjukkan adanya keluarga. Demikian pula firman Allah swt yang memerintahkan supaya jangan menyembah selain Dia dan hendaklah berbuat baik kepada ibu bapak dengan sebaik-baiknya (Q.S Al-Isra': 23). Dalam ayat ini juga disebutkan adanya Ibu, Bapak dan anak yang merupakan unsur keluarga. Dalam hadis riwayat Muslim, Nabi saw menjelaskan bahwa "Tidaklah dilahirkan anak itu kecuali telah membawa fitrah (kecendrungan untuk percaya kepada Allah), maka kedua orang tuanyalah yang menjadikan anak itu beragama Yahudi, Nasrani atau Majusi" (Sahih Muslim, juz, II: 68). Berdasarkan ayat dan hadis tersebut dapat dipahami bahwa keluarga yang asli atau fore family sistem adalah merupakan suatu kesatuan sosial yang terkecil terdiri dari suami, istri dan jika ada anak yang diawali dengan perkawinan. Atau dengan kata lain merupakan unit terkecil dalam masyarakat yang terdiri dari ayah, ibu, dan anak (Zuhdi, 1982: 7). Dengan demikian keluarga adalah institusi pertama dan terkecil yang ada dalam suatu masyarakat dimana terjadi hubungan-hubungan antar anggota keluarga atau hubungan antar keluarga dengan keluarga lainnya dalam suatu 
masyarakat. Berdasarkan institusi itulah individu-individu yang ada dalam keluarga berkembang serta memperoleh nilai, pengetahuan, keterampilan dan sikap yang kemudian dikembangkan dalam masyarakat dimana keluarga itu berada. Perbedaan institusi keluarga dengan yang lainnya adalah terletak pada ciri khas yang dimilikinya yaitu: Pertama, Adanya hubungan yang berpasangan antara kedua jenis kelamin yang berbeda laki dan perempuan. Kedua, Adanya perkawinan yang mengikat serta mengokohkan hubungan tersebut. Ketiga, Adanya pengakuan terhadap anak keturunan yang dihasilkan oleh hubungan perkawinan itu. Keempat, Terdapat pengelolaan hidup ekonomi secara bersama- sama. Kelima, adanya kehidupan bersama dalam rumah tangga (Maclver, 1971: 196).

2. Pengertian Pendidikan Keluarga

Sebelum membahas pengertian pendidikan keluarga menurut Islam, terlebih dahulu akan dibahas secara singkat pengertian pendidikan secara umum dan pengertian pendidikan Islam. Hal ini dimaksudkan untuk memberikan gambaran tentang pendidikan Islam tersebut.

Para ahli pendidikan di Barat mengartikan pendidikan sebagai proses. Adler (1962: 209) mengartikan pendidikan sebagai proses dimana semua kemampuan manusia (bakat) dan kemampuan yang diperoleh dapat dipengaruhi pembiasaan, disampurnakan oleh kebiasaan-kebiasaan yang baik melalui sarana yang secara artistik dibuat dan dipakai oleh siapapun untuk membantu dirinya atau orang lain mencapai tujuan yang ditetapkan yaitu kebiasaan yang baik. Sedangkan Herman (1962: 185) berpendapat bahwa pendidikan harus dipandang sebagai suatu proses penyesuaian diri manusia secara timbal balik dengan alam sekitar, dengan sesama manusia dan dengan tabiat dan 
dengan tabiat tertinggi dari kosmos. Sedangkan William Me Gucken, sebagaimana dikutip Arifin (1994: 13) berpendapat, bahwa pendidikan diartikan oleh ahli scholastik, sebagai suatu perkembangan dan kelengkapan dari kemampuan-kemampuan manusia baik moral, intelektual, maupun jasmaniah yang diorganisasikan atau untuk kepentingan individu atau sosial dan diarahkan kepada kegiatan-kegiatan yang bersatu dengan penciptaan sebagai tujuan akhirnya.

Pendidikan dengan demikian memiliki fungsi bimbingan dan pengarahan ke arah tujuan akhir yang lebih baik. Herman (1962: 185) menyebutkan hakikat pendidikan sebagai "membentuk manusia dalam citra Tuhan". John Dewey sebagaimana dikutip Idris (1981: 9) mengartikan pendidikan sebagai proses pembentukan kecakapan-kecakapan fundamental secara intelektual dan emosional kearah alam dan sesama manusia.

Konsep pendidikan Islam, mengacu kepada makna dan asal kata pendidikan itu sendiri dalam hubungannya dengan ajaran Islam, sebagaimana menurut Tafsir (1995: 109) bahwa istilah yang biasa digunakan dalam pendidikan Islam, yaitu: alTarbiyah, al-Ta'alim dan al-Ta'dib. Tarbiyah memiliki makna memelihara, membesarkan dan mendidik, dan dalam tarbiyah terkandung makna 'allama.

Berdasarkan pengertian tersebut, maka tarbiyah didefinisikan sebagai proses bimbingan terhadap potensi manusia secara maksimal agar menjadi bekal dalam menghadapi kehidupan. Namun Attas (1986: 21) merujuk makna pendidikan dari konsep ta'dib, karena pendidikan Islam lebih berorientasi pada ta'dib. Ta 'dib baginya hanya mencakup pengertian pendidikan untuk manusia, berbeda dengan tarbiyah yang memiliki 
pengertian, serta cakupan objek yang sangat luas.

Ketiga istilah tersebut merujuk kepada Allah. Tarbiyah ditengarai merupakan bentukan kata dari Rabbul 'Alamin, sedangkan ta'lim kosakata awal adalah 'allama, juga merujuk kepada Allah sebagai zat yang Maha 'Alim, selanjutnya ta'dib sebagai makna pernyataan Rasulullah SAW "addabani rabbi fa akhsana ta'diiby" untuk memperjelas bahwa sumber utama pendidikan adalah Allah SWT.

Dengan demikian pengertian pendidikan Islam dapat diuraikan sebagai upaya untuk menyeimbangkan, mendorong serta mengajak manusia lebih maju dengan berdasarkan nilai-nilai yang tinggi dan kehidupan yang mulia, sehingga terbentuk pribadi yang lebih sempurna, baik yang berkaitan dengan akal, perasaan maupun perbuatan (Jamali, 1981: 30).

Ada beberapa pandangan para ahli tentang pendidikan keluarga, misalnya menurut Gordon (1995) bahwa pola pendidikan yang diterapkan oleh orang tua dalam keluarga, terhadap anakanak dibedakan menjadi tiga yaitu:

a. Pola otoriter atau sering disebut metode orang tua menang anak kalah. Dalam pola ini apabila terjadi konflik antara orang tua dengan anak, maka orang tualah yang akan memutuskan cara pemecahannya.

b. Pola permisif atau metode anak menang dan orang tua kalah. Dalam pola ini orang tua menyerahkan semua keputusan pemecehan masalah kepada anak.

c. Pola demokratis atau metode anti kalah, yaitu setiap pemecahan masalah selalu dilakukan bersama-sama antara orang tua dengan anak dan keputusan diterima oleh kedua belah pihak. 
Sedangkan Syamsudin (1994: 56) berpendapat bahwa pola pendidikan keluarga itu dikategorikan kedalam tiga yaitu: Pertama, Orang tua yang selalu memperhatikan anak. Perilaku ini dapat diketahui dari sikap orang tua yang selalu melindungi dan memanjakan anak, sehingga anak-anak menjadi selalu tergantung kepada kedua orang tuanya. Kedua, Orang tua yang bersikap menolak dan membiarkan anak. Perilaku ini dapat diketahui dari sikap acuh orang tua terhadap permasalahan yang dihadapi anak. Ketiga, Orang tua yang bersikap menerima keadaan anak. Sikap ini merupakan perpaduan antara sikap menolak dan sikap memperhatikan anak. Sikap menerima anak merupakan wujud tanggung orang tua terhadap amanah yang diberikan Allah kepadanya. Orang tua dapat menerima keadaan anak, kemudian mendidik dan mengembangkan potensi yang dimilikinya menuju terbentuknya anak saleh sebagaimana yang dikehendaki oleh Agama Islam.

Pendidikan keluarga (anak) menurut ajaran Islam di dibagi kedalam tiga tahapan yaitu: tahap persiapan mendidik, tahap mendidik dalam kandungan dan tahap mendidik setelah lahir. Tahap persiapan pendidikan keluarga (anak) dimulai sejak pemilihan calon istri atau suami.

Konsep Islam tentang pemilihan jodoh adalah bahwa perempuan itu dinikahi kerena empat pertimbangan yaitu kekayaan, keturunan, kecantikan dan keberagamaannya. Dari keempat pertimbangan itu maka diupayakan untuk mendapat perempuan yang beragama, karena yang demikian itu akan beroleh keuntungan (H.R Abu Ya'la dan Ali bin Abi Thalib). Pertimbangan lebih mengutamakan perempuan yang beragama itu bahwa perempuan itu adalah tempat menanamkan benih 
keturunan, maka apabila keadaan tanahnya tidak baik, maka akan melahirkan anak keturunan yang tidak baik. Oleh karena itu, dalam hadis dari Aisyah, Rasul SAW mengingatkan kaum laki-laki agar berhati-hati memilih perempuan (tempat penaburkan) air mani dan nikahilah orang yang sepadan (H.R Ibnu Majah dan Al-Hakim). Kedua hadis ini menunjukkan bahwa seorang laki-laki apabila hendak menikah terlebih dahulu harus memilih calon istrinya dengan memperhatikan aspek keberagamaan, karena istri adalah ladang tempat menanam calon anak. Ketepatan dalam menentukan pilihan adalah ketepatan menentukan masa depan anak. Rasul SAW juga menganjurkan agar dalam memilih calon suami haruslah lakilaki yang memiliki keberagamaan yang baik, artinya laki-laki yang ta'at beribadah, akhlaknya baik, sebagaimana hadis Rasul SAW yang dinukilkan secara marfu "'bahwa apabila datang laki-laki kepadamu untuk meminang putrimu yang agama dan akhlaknya baik, maka kawinilah putrimu dengan laki-laki tersebut. Sebab jika tidak dilakukan maka, akan terjadilah fitnah dan bencana yang banyak (H.R At-Turmuzi). Hal ini berarti keberagamaan seorang laki-laki juga menjadi pertimbangan penting dalam memilih calon suami. Karena watak keturunan itu akan mempengaruhi anak, sehingga perlu memilih laki-laki yang saleh (Hadis marfuq, HR. Ibnu Adi). Selanjutnya ketika akan dilangsungkannya akad nikah, kedua calon suami-istri masih perlu diberi nasehat atau penjelasan tentang berbagai hal mengenai ajaran agama Islam, terutama tentang hidup berumah tangga. Hal ini menunjukkan bahwa suami-istri harus benar-benar mempersiapkan diri memasuki kehidupan berumah tangga, agar memperoleh kehidupan berkeluarga yang mawaddah warahmah. 
Tahap kedua adalah mendidik anak dalam kandungan. Setelah diketahui istri mengandung, maka pendidikan dalam kandungan harus sudah dimulai secara aktif. Dari segi pertumbuhan dan kesejahteraan fisiknya, janin dalam kandungan harus dijaga melalui pemenuhan makanan yang mengandung gizi seimbang, dan pemeliharaan kesehatan ibunya. Dari segi psikologisnya janin tersebut dipelihara melalui pembinaan suasana rumah tangga yang kondusif, sehingga ibu yang mengandungnya merasakan ketenangan, kenyamanan, ketenteraman dan kestabilan emosi. Semasa istri mengandung, banyak perubahan yang terjadi, baik perubahan fisik maupun perubahan psikis. Oleh karena itu, banyak kebutuhan yang harus dipenuhi oleh suami, agar bayi berkembang dalam keadaan baik dan normal. Kebutuhan istri yang perlu mendapatkan perhatian adalah kebutuhan akan perhatian, kebutuhan akan kecintaan ekstra, kebutuhan makanan ekstra, kebutuhan akan pengabulan, kebutuhan akan penghargaan, kebutuhan akan ketenteraman, kebutuhan akan perawatan dan kebutuhan akan keindahan (Baihaqi dalam Tafsir, 1996: 38-44). Demikian juga pendidikan agama sudah mulai ditanamkan kepada calon bayi, misalnya ibunya harus rajin beribadah, membaca al-Qur'an, dan berakhlak baik dan sebagainya. Pentingnya pendidikan dalam kandungan ini didasarkan bahwa ketika bayi masih dalam kandungan ibunya terjadilah dialog antara Allah SWT dengan calon bayi, sebagaimana firman Allah " Dan ingatlah ketika Tuhanmu mengeluarkan keturunan anak-anak Adam dari sulbi mereka dan Allah mengambil kesaksian terhadap nyawa mereka 'alu berfirman Bukankah Aku ini Tuhanmu ? Mereka menjawab: Betul (Engkau Tuhan kami) kami menjadi saksi (Allah melakukan yang demikian itu) agar pada hari qiamat nanti 
kamu tidak mengatakan sesungguhnya kami (Bani Adam) adalah orang-orang yang lengah terhadap ke-Esaan Tuhan (Q.S Al-A'raf: 172).

3. Metode Pendidikan Keluarga

Metode berasal dari bahasa latin "meta" yang berarti melalui dan "hodos"yang berarti jalan atau ke atau cara ke. Dalam bahasa Arab metode disebut "Thariqah" artinya jalan, cara, sistem atau ketertiban dalam mengerjakan sesuatu. Sedangkan menurut istilah ialah suatu sistem atau cara yang mengatur suatu cita-cita. (Uhbiyati, 1998: 123). Metode adalah cara yang teratur dan terpikir baik-baik untuk mencapai maksud, cara kerja yang bersistem untuk memudahkan pelaksanaan suatu kegiatan guna mencapai tujuan (Depdikbud, 1989: 581).

Metode yang dimaksud disini adalah cara-cara yang digunakan keluarga untuk mendidik anak-anak atau anggota keluarga lainnya. Metode tersebut digunakan untuk menuntun atau membimbing anak dalam masa pertumbuhannya agar kelak menjadi manusia berkepribadian muslim yang diridai oleh Allah. Oleh karena itu, metode pendidikan ini harus searah dengan alQur'an dan as-Sunah atau dengan kata lain tidak boleh bertentangan dengan al-Qur'an dan As-Sunah.

Bagaimana bentuk metode pendidikan keluarga? Oleh karena pendidikan keluarga dalam Islam merupakan pendidikan yang penekanannya pada pendidikan aspek jasmani, ruhani dan akal, maka apa yang menjadi metode pendidikan Islam adalah merupakan metode yang tepat dijadikan metode pendidikan keluarga.

Menurut Quthub (1984: 324-330), bahwa metode pendidikan Islam (metode pendidikan keluarga) adalah dengan metode keteladanan, nasehat, pembiasaan, hukuman dan 
ganjaran. Selanjutnya metode-metode tersebut akan diuraikan berikut ini:

a. Metode Keteladanan

Keteladanan adalah makna yang diambil dari kata uswah hasanah. Secara terminologi kata al-Uswah (alUswatun ) berarti orang yang ditiru. Sedangkan hasanah berarti baik. Dengan demikian uswatun hasanah adalah contoh yang baik, kebaikan yang ditiru, contoh identifikasi, suri teladan atau keteladanan (Suparta, 2003: 199). Pengertian uswatun hasanah banyak ditemukan dalam alQur'an antara lain "suri teladan yang baik pada diri Ibrahim dan orang-orang yang bersama denganya (Q.S. Al-Mumtahanah: 4), yaitu bagi orang-orang yang mengharap pahala Allah dan keselamatan pada hari kemudian (Q. S. Al-Mumtahanah: 6). Dengan demikian uswatun hasanah adalah keteladanan yang baik. Selain menjelaskan makna uswatun hasanah ayat-ayat tersebut menunjukkan bahwa betapa pentingnya menggunakan cara keteladanan dalam mendidik. Kepentingan penggunaan keteladanan itu dapat diketahui pula ketika Allah menegur orang-orang yang menyampaikan pesan kepada orang lain, sementara mereka tidak mengamalkan sebelumnya. "Mengapa orang-orang yang beriman mengatakan apa yang tidak mereka perbuat ? Amat besar kebencian Allah kepada orang yang mengatakan apaapa yang tidak mereka kerjakan (Q. S. al-Shaff: 2).

Pendidikan dengan keteladanan adalah pendidikan dengan memberi contoh yang, baik perkataan, perbuatan maupun cara berpikir. Allah SWT mengutus Nabi Muhammad sebagai figur teladan yang baik (Q.S Al-Ahzab: 21). Siti Aisyah sendiri mengatakan bahwa akhlak Rasul SAW 
itu adalah al-Qur'an. Oleh karena kepribadian, karakter, perilaku dan interaksi Rasul SAW dengan manusia merupakan pengejawantahan hakikat al-Qur'an. Lebih dari itu bahwa akhlak beliau merupakan perwujudan landasan dan metode pendidikan yang terkandung dalam al-Qur'an (An-Nahlawi, 1995: 260). Kelebihan mendidik dengan keteladanan ini setidaktidaknya untuk mengajarkan pengetahuan-pengetahuan yang bersifat praktis, seperti gerakan salat, sehingga sangat mudah ditangkap dan dipahami anak. Karena memang pada umumnya dalam belajar orang lebih mudah menangkap halhal yang konkrit. Menurut Ulwan (1978: 633), misalnya bahwa pendidik akan merasa mudah menyampaikan pesan secara lisan, akan tetapi anak akan mengalami kesulitan untuk memahami pesan tersebut, apabila anak melihat pendidik tidak memberi contoh tentang pesan yang disampaikannya.

b. Metode Nasehat

Dalam bahasa Arab kata "wa'azhahu, ya'izhuhu, wa'zhan, wa'izhah, wamau'izhah" (An-Nahlawi, 1995: 289) yang berarti mengingatkannya terhadap sesuatu yang dapat meluluhkan hatinya dan sesuatu itu dapat berupa pahala maupun siksa yang menyebabkan ia menjadi ingat. Sedangkan Ridha dalam tafsir Al-Manar ketika menafsirkan ayat 232 al-Qur'an surah al-Baqarah mengatakan bahwa "Al-wa'zhu" berarti nasehat dan peringatan dengan kebaikan yang dapat melembutkan hati serta mendorong untuk beramal. Secara etimologis kata nasehat itu dalam bahasa Arab berakar pada kata "nashaha" yang mengandung pengertian bersih yang tiada bercampur (Yunus, 1989: 454), "Rajulun nasheha al-jaib " yang berarti orang yang tidak memiliki sifat penipu; dan "al-Nasheh" berarti madu murni (Aly, 1999:192). 
Berdasarkan pengertian inilah, An-Nahlawi (1999: 253) mengatakan bahwa indikasi nasehat yang tulus itu ialah orang yang memberi nasehat itu tidak berorientasi pada kepentingan material pribadi. Oleh karena itu, pendidik yang memberi nasehat secara tulus hendaknya menghindarkan diri dari sifat riya' dan menuntut balasan, agar tidak menodai keikhlasannya yang mengakibatkan hilangnya pengaruh terhadap jiwa anak didik. Dengan demikian yang dimaksud dengan nasehat, ialah penjelasan tentang sesuatu kebenaran dan kemaslahatan yang bertujuan untuk menghindarkan orang yang diberi nasehat itu dari bahaya dan menunjukkannya ke jalan yang mendatangkan manfa'at dan kebahagiaan (An-Nahlawi, 1979: 253). Nasehat berarti memberi petunjuk kepada jalan yang benar dan juga mengatakan sesuatu yang benar dengan cara melunakkan hati. Nasehat harus berkesan dalam jiwa atau mengikat jiwa dengan keimanan dan petunjuk. "sekiranya mereka melaksanakan pengajaran yang diberikan kepada mereka tentulah hal yang demikian itu lebih baik bagi mereka dan lebih menguatkan (iman) mereka (Q.S An-Nisa': 66). Dengan demikiam dapatlah dikatakan bahwa nasehat itu adalah suatu upaya yang dilakukan oleh pendidik kepada anak didik atau orang tua kepada anak-anaknya dengan memberi penjelasan tentang sesuatu hal yang dapat menyentuh dan menyejukkan hati, sehingga terjadi perubahan sikap dan perilaku menuju kepada hal-hal atau amalan kebaikan yang bermanfa'at bagi kehidupan peribadi, keluarga maupun masyarakat yang dapat mendatangkan kebahagiaan hidup dunia dan akhirat. 
Dalam memberikan nasehat dapat digunakan beberapa bentuk menurut An-Nahlawi (1995: 289) sebagai berikut:

1) Dalam bentuk memberikan penjelasan tentang kebenaran dan kepentingan sesuatu dengan tujuan agar orang yang di nasehati itu menjauhi dan meninggalkan suatu kemaksiatan kemudian melakukan hal-hal yang baik, bermanfa'at serta menimbulkan kebahagiaan. Hal yang terpenting dalam penasehatan adalah agar dilaksanakan secara tulus ikhlas tanpa mengharapkan imbalan, sebagaimana dikisahkan dalam dialog antara para Rasul dengan kaumnya yang terdapat dalam al-Qur'an surat al-Furqan ayat 57" Bahwa aku tidak meminta upah sedikitpun kepada kamu dalam menyampaikan risalah ini (Quthub, Juz 9, 2000: 167) dan para rasul seperti Nuh, Hud, Saleh, Luth dan Syuaib tidak juga mengharapkan upah dari kaumnya, kecuali mengharapkan upah dari Allah Tuhan Semesta Alam sebagaimana dikisahkan dalam surat Asy-Syu'ara, 109 dan seterusnya (Katsir, 4: 258).

2) Dalam bentuk memberi peringatan, yaitu menjelaskan kembali tentang konsep dan peringatan kedalam ingatan anak didik yang dengan demikian dapat menggugah perasaan, afeksi dan emosi yang mendorongnya untuk segera berta'at kepada Allah SWT dengan melaksanakan berbagai perintah-Nya dalam berbagai bentuk amalan salehan. Untuk melaksanakan bentuk peringatan itu dapat dilakukan dengan cara: Pertama, Peringatan melalui kematian, sebagaimana yang dilakukan oleh Umar bin Khattab terhadap dirinya sendiri yang diawali dengan mengatakan kematian pasti datang 
pada sa'atnya, dan tidak seorangpun dapat menghindarinya. Kemudian merenungkan azab kubur dan siksa neraka. Dengan peringatan ini menimbulkan rasa takut Umar kepada Allah SWT serta perhitungan dihari kemudian, sehingga Umar mengucurkan air mata sehingga membasahi kedua pipinya (An-Nahlawi, 1995: 291). Kedua, Peringatan melalui sakit. Sakit merupakan musibah yang dapat menimpa setiap orang yang kedatangannya sering pula mengejutkan manusia. Oleh karena itu manusia diminta waspada dan bersabar apabila mengalami sakit. Dengan cara mengingat akan peristiwa sakit ini anak didik atau anggota keluarga akan senantiasa waspada dan terdorong untuk selalu mempersiapkan diri dengan berbagai amal kebaikan yang sebanyak-banyaknya. Dalam sebuah hadis Nabi mengingatkan manusia agar bekerja dan beramal sebanyak-banyaknya untuk dunia, seakan-akan manusia hidup selamanya, tetapi nabi juga mengingatkan manusia agar banyak beramal untuk bekal akhirat seakan-akan kematian akan datang besok hari. (H.R. Muslim). Ketiga, Peringatan melalui yaumil hisab, yaitu suatu hari Allah memperhitungkan amal perbuatan manusia ketika hidup di dunia. Tidak ada manusia yang bisa lolos dari perhitungan ini. Sekecil apapun amal perbuatan yang dilakukan manusia pasti akan diperlihatkan oleh Allah (Q.S al-Zalzalah: 7-8). Melalui cara ini anak didik diperingatkan, sehingga dapat mendorong mereka agar berhati-hati baik dalam berbicara, bersikap maupun berbuat.

Untuk menyampaikan nasehat yang baik diperlukan cara-cara tertentu agar dalam pelaksanaannya 
lebih efektif. Rasul SAW menuntunkan kepada umatnya agar dalam memberikan nasehat kepada orang lain menggunakan berbagai cara sebagaimana dikemukakan Ulwan (1988: 105-113) sebagai berikut:

a) Menggunakan metode kisah. Melalui metode kisah akan timbul kehangatan perasaan kehidupan dan dinamisnya jiwa anak, sehingga mendorong untuk mengubah perilaku serta memperbaharui tekad, selaras dengan tuntunan, pengarahan, penyimpulan dan pelajaran yang dapat diambil dari kisah tersebut. Ada kisah yang berkaitan dengan tauhid. Beliau menerangkan keimanan kepada Allah, keharusan bersabar terhadap takdirnya serta mengisahkan bagaimana orang-orang bertauhid dahulunya diintimidasi, di teror dan dibunuh. Dalam hadis riwayat Muslim adapula kisah yang mengarahkan manusia kepada kebiasaan bersedekah untuk mensyukuri nikmat Allah. Contoh kisah tersebut adalah kisah tiga orang, sibuta, si belang dan si botak. Dalam kisah ini diceritakan bahwa ketiga orang ini sangat menderita karena keadaannya masing-masing, maka Allah mengutus malaikat untuk menyembuhkan penyakit ketiga orang tersebut. Dengan kesembuhan itu ketiga orang tersebut akhirnya menjadi kaya raya. Namun dari ketiga orang itu hanya sibuta yang bisa mensyukuri nikmat Allah dengan bersedekah. Sedangkan si belang dan si botak tidak mau bersyukur. Akibatnya Allah mengembalikan kedua orang tersebut kepada keadaan semula (Muslim, Juz 3: 390). Demikianlah kisah ini mengandung manfa'at yang sangat besar untuk 
menggugah orang yang dinasehati agar mengambil sikap yang terpuji seperti suka bersedekah.

b) Melalui metode dialog. Dengan cara menyampaikan pertanyaan atau mengemukakan suatu persoalan untuk membangkitkan perhatian, menggerakkan kecerdasan dan memberikan nasehat, sehingga berbekas dihati anakanak. Rasul SAW memberi contoh melalui sebuah hadis "Apakah pendapat kalian (para sahabat) apabila didepan rumah salah seorang diantara kalian terdapat sebuah sungai lalu ia mandi sebanyak lima kali dalam sehari, apakah masih tersisa daki di badannya ? Para sahabat menjawab tidak sedikitpun tersisa daki dibadannya. Lalu Nabi mengatakan demikianlah orang yang salat lima kali dalam sehari, yang dengannya Allah menghapus kesalahan -kesalahannya."

c) Memulai nasehat dengan bersumpah kepada Allah SWT. Sumpah yang dilakukan ini bertujuan untuk menarik perhatian orang yang akan diberi nasehat, karena pentingnya isi nasehat yang harus dikerjakan atau dijauhi. Nabi SAW memberi contoh "Demi Allah tidak beriman, demi Allah tidak beriman, demi Allah tidak beriman, dikatakan, siapa wahai Rasul SAW ? tanya para sahabat. Lalu nabi menjawab, Orang yang tidak memberi rasa aman kepada tetangganya karena kejahatannya". (H.R Al-Bukhari).

d) Menyelingi nasehat dengan bercanda. Bercanda ketika memberi nasehat dimaksudkan untuk menggerakkan akal, menghilangkan rasa jenuh dan menimbulkan daya tarik, sehingga anak-anak atau orang yang diberi nasehat merasa, nasehat yang diberikan tersebut tetap 
menarik dan dapat diterima akal.

e) Sederhana dalam memberi nasehat. Nasehat yang akan diberikan terlebih dahulu harus dipertimbangkan situasi dan kondisi orang yang akan diberi nasehat. Hindari memberi nasehat terlalu lama dan terlalu banyak, yang dapat membosankan, sehingga maksud nasehat juga tidak berhasil. Jangan memberi nasehat kepada orang yang sedang sakit yang tidak memungkinkan ia mampu menyerap isi nasehat tersebut, kecuali memang orang yang sedang sakit itu memerlukan nasehat, tetapi yang ringan-ringan saja. Nabi SAW memberi contoh sederhananya dalam memberi nasehat dengan menggunakan waktu singkat. "Rasul SAW tidak memperpanjang memberi nasehat pada hari Jum'at, hanya merupakan kata-kata yang sederhana" ( H.R Abu Daud).

f) Berwibawa dan berbekas. Nasehat yang akan diberikan hendaklah disampaikan dengan berwibawa, sehingga nasehat tersebut berbekas dihati pendengar atau orang yang diberi nasehat. Nasehat yang disampaikan dengan kata-kata yang dibuat-dibuat yang tidak timbul atas dasar keikhlasan tidak akan memberi pengaruh yang efektif, jika dibandingkan dengan nasehat yang diberikan melalui hati yang ikhlas, yang didasarkan oleh Iman dan Islam, maka akan lebih memberi pengaruh besar kepada hati orang yang penerima nasehat, sehingga akan lebih efektif. Karena itu kunci-kunci (Iman dan Ikhlas) untuk menyampaikan nasehat agar efektif perlu mendapat perhatian termasuk orang tua yang memberi nasehat kepada anak-anaknya. 
g) Nasehat dengan perumpamaan dan peragaan. Untuk memperjelas nasehat yang akan diberikan, Nabi SAW menggunakan perumpamaan yang dapat disaksikan secara fisik serta dalam jangkauan manusia, sehingga akan berbekas dihati dan akal. "Orang mukmin bagi orang mukmin lainnya laksana sebuah bangunan yang saling menguatkan dan lalu beliau menyilangkan antara jari-jarinya" (HR Muslim) (Al-Adawi, 1995:182).

h) Nasehat dengan mempergunakan kesempatan. Rasul SAW menggunakan kesempatan untuk memberi nasehat dan pelajaran.

i) Nasehat dengan menampakkan sesuatu yang haram. Rasul SAW mengambil sesuatu yang haram dan dilarang oleh agama, serta mengangkatnya dihadapan umum. Hal ini dilakukan untuk menunjukkan kepada halayak ramai bahwa inilah sesungguhnya barang yang diharamkan itu.

j) Nasehat dengan memperagakan gambaran. Rasul SAW menggariskan telunjuknya ditanah dihadapan para sahabat untuk memperjelas sebagian pemahaman yang penting dan mendekatkan kepada akal mereka sebagai gambaran yang lebih bermanfa'at.

k) Nasehat melalui amalan praktis. Rasul SAW memberikan contoh mengenai metode pendidikan, pengajaran dan pembinaan. Diantaranya adalah dengan cara memberi contoh cara berwudu dan mengerjakan salat. Nasehat dengan memilih yang lebih penting. Rasul SAW selalu memilih permasalahan yang dianggap lebih penting untuk dinasehatkan kepada para sahabat atau orang lain, seperti terjadinya hari qiamat, mempersiapkan 
amal saleh menghadapi hari qiamat dan lain lain.

c. Metode Pembiasaan

Pembiasaan berasal dari kata biasa yang berarti merupakan hal yang lazim; umum sudah tidak terpisahkan dari kehidupan sehari hari (Dep. Dikbud, 1989: 113). Kemudian ditambah kata "pem" dan akhiran "an" yang dapat berarti suatu proses penanaman kebiasaan. Kebiasaan (habit) ialah cara-cara bertindak yang persistent, uniform, dan hampir-hampir otomatis (Dahlan, 19....9: 7). Pembiasaan sebagai suatu metode pendidikan keluarga menjadi sangat penting karena pembiasaan yang sudah menjadi perilaku seseorang akan secara otomatis atau dengan sendirinya dilakukan. Seseorang yang telah mempunyai kebiasaan tertentu akan melaksanakannya dengan cepat, mudah dan dengan senang hati. Sesuatu yang sudah menjadi kebiasaan sejak kecil akan menjadi sulit untuk diubah setelah dewasa. Penggunaan metode pembiasaan dalam pendidikan keluarga ini berdasarkan pada al-Qur'an yang berkenaan dengan etika memasuki kamar orang tua yang hendaknya diperhatikan oleh anak-anak dan para pembantu (Q.S an-Nur: 58-59). Dalam ayat tersebut ada tiga waktu yang haras diperhatikan dengan cara meminta izin ketika akan masuk kamar orang tua yaitu: Pertama, Waktu siang yang biasanya orang tidur siang dan menanggalkan pakaian. Kedua, Waktu sesudah salat isya ketika orang biasanya akan tidur dan membuka pakaian. Ketiga, Waktu fajar pada sa'at orang masih tidur atau baru bangun tidur dan belum berpakaian rapi. Pembiasaan meminta izin ketika anak-anak akan memasuki kamar orang tua sejak kecil, akan menjadi perilaku positif sampai anak dewasa. Perintah meminta izin memasuki kamar orang tua 
pada tiga waktu tersebut adalah untuk menghindari anak-anak dari memandang hal-hal yang tidak semestinya yaitu melihat aurat orang dewasa yang dilarang oleh agama Islam.

Agar penerapan metode pembiasaan berjalan efektif sehingga mampu mencapai tujuan sebagaimana yang dikehendaki oleh pendidik, maka perlu memperhatikan syarat-syarat yaitu:

1) Pembiasaan itu dimulai sebelum anak melakukan hal-hal yang bertentangan dengan materi pendidikan yang akan dibiasakan.

2) Pembiasaan itu dilakukan secara terus menerus sehingga berjalan secara otomatis.

3) Pendidik hendaknya bersikap konsekuen, tegas dan teguh pendirian. Hindari kesempatan anak untuk melanggar pembiasaan.

4) Pembiasaan yang semula bersifat mekanistis harus diubah menjadi pembiasaan yang disenangi anak (Purwanto, 1995: 178).

Beberapa kebiasaan yang perlu ditanamkan kepada anak dalam periode mumayyiz sampai baligh menurut Halim (2001: 183-185) adalah:

1) Menanamkan kebiasaan beribadah. Kebiasaan beribadah seperti salat, puasa, zakat dan berdo'a sudah mulai ditanamkan kepada anak sejak mereka masih kecil. Sebagaimana perintah Rasul agar anak-anak diperintahkan untuk membiasakan salat ketika mereka berumur tujuh tahun (H.R. Abu Daud dan Hakim). Membiasakan beribadah kepada anak-anak tersebut dapat dilakukan secara mandiri atau berjamaah di masjid misalnya, sehingga akan menimbulkan rasa senang dan 
gembira karena dikerjakan secara bersama atau bahkan sesama anak-anak itu sendiri, mereka melakukannya tanpa suruhan atau perintah orang lain. Demikian pula halnya dengan berdoa, anak-anak supaya dibiasakan berdoa, misalnya doa minta ampun dari segala kesalahan, sehingga anak-anak tidak merasa terbebani apabila berbuat kesalahan terhadap Allah SWT, doa untuk orang tua, doa memohon tambahan ilmu dan kepandaian dan sebagainya.

2) Menanamkan kebiasaan hidup sehat. Hidup sehat adalah sebuah perilaku yang seharusnya menjadi hiasan hidup setiap orang mukmin. Karena hidup sehat secara lahir maupun batin akan sangat menunjang keabsahan ibadah kepada Allah SWT. Kebiasaan hidup sehat seseorang tidak bisa datang dengan tiba-tiba setelah ia tua, tetapi memerlukan pembiasaan. Karena itulah sejak kecil anakanak hendaknya dibiasakan dengan hidup sehat, bersih pisik maupun jiwanya dari penyakit hati seperti dengki sesama teman, membeci teman dan sebagainya. Membiasakan hidup sehat kepada anak-anak dapat diupayakan dengan selalu membawa anak berolah raga dan memberikan pengetahuan kesehatan secukupnya sebagai bekal dikemudian hari. Pembentukan jasmani yang sehat sangat bermanfa'at bagi pencegahan terhadap penyakit. Jadi hidup sehat merupakan benteng pertahanan dari serangan penyakit. Kebiasaan hidup sehat dengan berolah akan menguatkan tubuh yang diperlukan bagi setiap orang. Karena orang mukmin yang kuat adalah lebih baik dan lebih dicintai Allah dari pada orang mukmin yang lemah (H. R. Muslim). Hidup 
sehat dapat pula diupayakan dengan selalu menjaga kebersihan badan dari berbagai kotoran dan membersihkan lingkungan tempat tinggal. Karena bagi orang mukmin menjaga kebersihan merupakan bagian dari keimanannya.

3) Menanamkan kebiasaan bersikap ekonomis. Sikap ekonomis dapat berarti penghematan sekaligus memberdayakan terhadap apa yang dimiliki dan berupaya untuk menemukan sesuatu yang belum dimiliki. Bertindak hemat dan memanfa'atkan apa yang dimiliki haruslah dibiasakan kepada anak-anak sejak kecil dan dimulai dari hal-hal yang sederhana seperti menghemat menggunakan air pada saat mandi atau mencuci tangan, menghemat uang jajan yang diberikan orang tua dan sebagainya. Kebiasaan bersikap ekonomis akan mendorong anak-anak untuk berlaku disiplin, bekerja keras, berhemat serta menghargai sesuatu yang telah dimilikinya, termasuk berhemat dalam mengeluarkan tenaga atau energi, misalnya anak-anak jangan dibiarkan terlalu banyak berlari yang tidak bermanfa'at karena akan mengakibatkan lelah tubuh.

Selain hal tersebut di atas, anak-anak perlu dibiasakan berakhlak mulia dalam kehidupan sehari-harinya, seperti membiasakan mengucap salam ketika masuk rumah, meminta izin kepada orang tua apabila hendak pergi, membiasakan ketika masuk rumah dengan kaki kanan dan mambaca basmalah, berdo'a pada berbagai tempat dan situasi, seperti do'a masuk kamar kecil, berdo'a ketika berpakaian, membiasakan menjauhi kata-kata kotor. Kebiasaan ini akan terpatri di dalam hati anak-anak sampai mereka usia tua sebagaimana pepatah "alah bisa karena 
biasa" artinya kemampuan seseorang melakukan sesuatu karena telah menjadi kebiasaan sebelumnya.

Menurut Baihaqi AK, dalam Tafsir (1995: 52-54) metode pendidikan keluarga untuk anak prenatal adalah:

1) Metode kasih sayang. Kasih sayang adalah kebutuhan semua orang dalam kehidupan ini, termasuk seorang ibu yang sedang hamil. Sebagai sebuah metode mendidik, kasih sayang sangat perlu diterapkan oleh suami kepada istrinya yang sedang hamil. Karena dengan demikian istri akan menjadi tenang dan tenteram. Kondisi istri yang tenang dan tenteram akan mempengaruhi situasi rumah tangga sehingga menjadi rukun antara suami-istri, rumah tangga menjadi lingkungan yang baik dan Islami yang akan merangsang secara educative terhadap anak prenatal.

2) Metode beribadah. Dalam upaya mendidik anak prenatal beribadah merupakan metode yang sangat tepat. Seorang ibu hamil melakukan ibadah salat misalnya, maka dengan sendirinya ia telah membentuk lingkungan islami di dalam rumah tangganya. Lingkungan seperti ini akan merangsang secara educatif yang islami bagi anak prenatal yang sedang dikandungnya. Karena itu memang sebaiknya ibu yang sedang hamil banyak-banyak melaksanakan ibadah, terutama salat baik wajib maupun salat sunah.

3) Metode membaca al-Qur'an. Membaca al-Qur'an sebagai sebuah metode mendidik anak prenatal sangat baik dilakukan oleh ibu yang sedang hamil. Karena ketika ibu hamil melakukan hal itu berarti ia telah membina lingkungan rumah tangga yang islami yang akan mempengaruhi bagi anak yang sedang dikandungnya. 
Semakin sering ia membaca al-Qur'an berarti semakin terbinalah lingkungan islami tersebut sepanjang ia hamil. Berdasarkan hasil-hasil penelitian menunjukkan bahwa bayi yang sedang dalam kandungan responsif terhadap bacaan al-Qur'an dan mendapat rangsangan edukatif yang sangat positif. Karena itu sebaiknya selama ibu hamil senantiasa membaca al-Qur'an, yang akan memperoleh banyak keuntungan antara lain bahwa membaca alQur'an itu sebagai ibadah bagi pembacanya, akan mempengaruhi bayi dalam kandungan dan membentuk lingkungan rumah tangga yang Islami dan lain-lain.

4) Metode bercerita. Bercerita dapat digunakan sebagai metode mendidik anak prenatal. Melalui metode ini seorang ayah dapat bercerita kepada bayi dalam kandungan melalui istrinya. Cerita-cerita yang sangat perlu disampaikan misalnya cerita para nabi, sahabat nabi, para pejuang kemerdekaan bangsa dan para pahlawan yang telah mengorbankan jiwa.

5) Menunjukkan kesalahan dengan memutuskan hubungan atau meninggalkannya sebagaimana hadis yang dikeluarkan Nabi SAW ketika perang tabuk: "Bahwa Rasul tidak berbicara kepada kami selama lima puluh malam, sehingga turunlah ayat tentang taubat mereka dalam AlQur'an".

6) Menunjukkan kesalahan dengan memukul. Dalam hadis riwayat Ahmad, Abu Daud dan Hakim Rasul bersabda: "Perintahkanlah anakmu melakukan salat ketika berumur tujuh tahun dan pukullah mereka karena meninggalkan salat ketika berumur sepuluh tahun." (Al-Halwani, 1996: 101). Menghukum anak dengan memukul dapat diterapkan dalam 
mendidik anak, apabila tidak ada pilihan lain. Namun dalam penerapannya haruslah memperhatikan prinsip bahwa jangan melakukannya dihadapan orang banyak, sebab akan menimbulkan rasa malu kepada anak dan terhina yang mengakibatkan timbul rasa dendam kepada orang tuanya itu dan jangan mengakibatkan bahaya yang lebih besar, misalnya kerusakan tubuh anak. Karena sebenarnya pukulan itu hanya simbol, karena setiap pukulan dipersepsikan anak mengakibatkan rasa sakit, walaupun sesungguhnya tidak setiap pukulan itu menimbulkan rasa sakit.

7) Menunjukkan kesalahan dengan memberi hukuman untuk menjerakan pelakunya. Dalam hukum qishash misalnya dijelaskan bahwa dalam qishash itu terdapat jaminan kelangsungan hidup bagi orang-orang yang selalu menggunakan akal (Q. S al-Baqarah: 179). Penggunaan metode hukuman dalam mendidik anak sebenarnya bertujuan agar anak-anak jera dan berhenti melakukan kesalahan serta berubah dari perilaku buruk kepada perilaku terpuji yang dapat menghiasi hidupnya. Demikianlah cara-cara Rasul SAW dalam memperbaiki kesalahan yang dilakukan oleh orang lain yang diharapkan akan menimbulkan dampak yang lebih baik, yaitu perubahan perilaku kearah perilaku yang terpuji yang menjadi hiasan hidup setiap orang mukmin. Menurut AlAhwani (1977: 153) dikalangan umat Islam biasanya menerapkan empat macam hukuman, yaitu: Pertama, hukuman siksaan (Intiqamiyatun). Kedua, hukuman pencegahan (raadiatun). Ketiga, hukuman peringatan 
(wa'izhatun) dan. Keempat, hukuman perbaikan (mashlihatun). Hukuman siksaan dikalangan umat Islam kebanyakan tidak diterapkan. Karena siksaan yang demikian itu biasanya dilandasi oleh sifat kemarahan, yang selalu mengakibatkan kerusakan karena tidak dipertimbangkan oleh akal sehat. Dalam Islam juga dikenal hukuman badan ('Uqubat al-Badaniyah) atau hukuman jasmaniyah. Namun hukuman semacam ini baru dapat diterapkan apabila memenuhi persyaratan: Pertama, hukuman badan hanya dapat diterapkan kepada anak yang sudah berusia sepeluh tahun, sedangan anak yang belum berumur sepuluh tahun hukuman badan tidak boleh diterapkan. Kedua, Penerapan hukuman badan ini apabila situasinya sangat memerlukan. Apabila terpaksa dilakukan hukuman badan ini, maka hendaklah disertai kasih sayang, bukan kesempatan untuk melampiaskan kemarahan orang tua atau guru. Ketiga, pukulan yang diberikan hendaklah berupa cambukan yang lembut yang tidak menimbulkan kerusakan pada anak dan terutama jangan memukul pada daerah yang berbahaya, seperti muka dan kepala anak (Syalabi, 1973: 267). Apabila orang tua atau guru akan menerapkan hukuman pukulan menurut Al-Qabisy dalam Al-Ahwani (1977: 53) haruslah memenuhi persyaratan, yaitu: Pertama, jangan memukul kecuali terhadap suatu kesalahan. Kedua, pukulan dilakukan sekedar atau setarap dengan kesalahannya. Ketiga, jumlah hukuman pukulan satu sampai tiga kali pukulan dan sebanyak-banyaknya sepuluh kali pukulan. Keempat, pukulan lebih dari sepuluh kali dapat dilakukan apabila anak telah mendekati ihtilam (bermimpi yang 
menunjukkan tanda sudah baligh). Kelima, sifat pukulan tidak boleh melebihi batas kebencian. Keenam, pukulan dilakukan secara langsung oleh guru dan jangan hanya memukul salah seorang saja diantara dua anak yang bersalah. Ketujuh, jangan memukul pada bagian tubuh yang berbahaya seperti muka dan kepala. Kedelapan, menggunakan alat pemukul yang kecil bukan alat pemukul yang besar. Oleh karena itu Sayyid Quthub (2000: 234) mengatakan pendidikan yang lemah-lembut seringkali dapat menyentuh perasaan dan berhasil untuk mendidik anak, akan tetapi yang terlalu lembut dan menyentuh perasaan akan berpengaruh jelek terhadap jiwa, sehingga jiwa tidak stabil, jiwa yang selalu dimanjakan akan tidak mampu menahan pekerjaan berat yang melelahkan dan sulit diatasi, yang mengakibatkan jiwa selalu goyah, sehingga kebahagiaan, ketenteraman tidak akan diperoleh.

d. Mendidik dengan Metode Ganjaran atau hadiah

Dalam Kamus Besar Bahasa Indonesia (1989: 253, 298), ganjaran berarti menghadiahi atau membalas jasa. Sedangkan penghargaan adalah perbuatan menghargai atau menghormati. Jadi penghargaan yang dimaksud disini ialah menghargai atau menghormati anak-anak yang telah mampu berkarya atau menghasilkan sesuatu produk kebaikan. Ganjaran atau penghargaan ini bertujuan agar anak-anak merasa senang karena karya atau hasil kerjanya diakui keberadaannya dan atau dihormati oleh orang tua sebagai sebuah hasil kerja kebaikan. Dengan demikian diharapkan anak-anak akan lebih bersemangat, berkemauan keras, dan bekerja untuk menghasilkan karya-karya kebaikan, sehingga ia merasakan 
benar bahwa berbuat kebaikan itu ternyata mempunyai nilai bukan saja menurut pandangan Allah SWT, tetapi juga dari pandangan manusia.

Mengenai penghargaan terhadap karya kebaikan ini dapat diketahui dari firman Allah SWT, misalnya "Tidak ada balasan kebaikan kecuali kebaikan pula (Q.S ar-Rahman: 60). Demikian pula penghargaan yang dijanjikan Allah kepada orang-orang yang berbuat baik yaitu "bahwa orang yang beriman dan berbuat baik akan disediakan surga-surga yang di dalamnya mengalir sungai-sungai. Para penghuni surga itu akan memperoleh rizki dari buah-buahan dan disediakan istri-istri yang suci (Q.S al-Baqarah: 25). Sifat surga yang di bawahnya mengalir sungai-sungai yakni dari bawah pohon dan kamarkamar surga. Sungai-sungai surga itu mengalir bukan dari dalam saluran yang panjang, tetapi ia bermuara ke dalam telaga Kautsar yang kedua sisinya dinaungi kubah mutiara yang berongga dan tidak bertentangan antara kedua sisinya, tanah surga itu merupakan kesturi yang mengkristal dan humusnya berupa mutiara dan permata (Ar-Rifa'i, 1989: 97). Dalam beberapa ayat lain Allah juga menggambarkan bagaimana Allah memberikan balasan kepada orang-orang yang telah menunjukkan karya atau prestasi, misalnya bahwa "orangorang yang beriman dengan sebenar-benarnya akan memperoleh ketinggian beberapa derajad disisi Allah, ampunan dan rizki yang mulia (Q.S al-Anfal: 4). Kemudian dalam surah Maryam dijelaskan pula bahwa "orang-orang yang bertaubat, beriman dan beramal saleh akan masuk surga dan tidak dianiaya (dirugikan) sedikitpun (Q.S. Maryam: 60). Allah akan memberikan balasan kepada orang-orang yang bertakwa dengan "mengadakan jalan keluar, memberi rizki dari jalan yang tidak 
diduga-duga, akan mencukupkan keperluannya, kemudahan dalam urusannya, menghapus kesalahan-kesalahannya dan akan melipat gandakan pahalanya (Q.S ath-Thalaq: 2-5).

Untuk memberikan penghargaan kepada anak-anak yang telah membuat prestasi kebaikan dapat menggunakan berbagai bentuk diantaranya menurut Masbuhin (2002: 156) adalah:

1) Dalam bentuk ucapan yang menyejukkan hati. Dengan ungkapan kata-kata yang menyejukkan hati dan menyenangkan pikiran untuk menghargai karya anak-anak, lebih baik dari pada memberikan penghargaan dalam bentuk benda. Setiap ucapan yang menyenangkan dan menyejukkan hati akan mendorong anak untuk berbuat lebih baik lagi serta menumbuhkan sikap percaya diri, menghormati orang lain, karena ia pun merasa dihormati dan dihargai sehingga ia akan bercita-cita tinggi menghadapi masa depan hidupnya.

2) Orang tua menempatkan diri sebagai pendengar yang baik. Salah satu sifat anak ialah ingin didengar. Betapa senangnya anak-anak ketika mereka berbicara orang tua memperhatikan dan mendengarnya dengan serius. Karena itu salah satu bentuk yang dapat digunakan untuk menghargai karya anak-anak ialah dengan cara memperhatikan pembicaraan mereka, mendengar dengan serius dan jangan memalingkan muka pada waktu anak berbicara, dan jangan memotong pembicaraan mereka. Biarkan mereka bebas mengemukakan pikiran dan pendapatnya, karena hal itu sangat menyenangkan hati mereka. Perlihatkan bahwa orang tua terkesan dengan pembicaraan atau cerita anak-anak tersebut. Hal ini 
menunjukkan bahwa orang tua telah melakukan sesuatu yang sangat baik bagi anak-anaknya. Karena anak-anak merasa bahwa apa yang ia sampaikan mempunyai nilai atau bermakna dihadapan orang tuanya. Hal ini juga akan mendidik sikap keterbukaan anak kepada orang tua dan demokratis.

3) Mencium anak. Ciuman terhadap anak merupakan wujud rasa cinta dan kasih sayang orangtua kepada anak. Anak akan merasa senang setelah dicium orang tuanya, karena mereka merasa dicintai dan disayangi yang sekaligus dihargai keberadaannya. Jadi ketika anak-anak memperlihatkan karya kebaikannya pada sa'at itulah sebaiknya orang tua memberikan penghargaan dengan mencium anaknya, tentu anak-anak yang masih kecil. Karena dengan begitu anak merasa bahwa karya kebaikannya telah memperoleh penghargaan dari orang tuanya.

4) Memberi tugas. Ketika seseorang diberi tugas yang sesuai dengan kemampuannya ia akan merasa bahwa ia diperlukan dan dihargai kemampuannya. Anak-anak akan merasa senang apabila orang tua memberi tugas yang sesuai dengan kemampuannya, bahkan sesuai dengan keinginannya. Karena dengan begitu anak-anak merasa bahwa mereka tidak diabaikan dan diberi kesempatan untuk melakukan sesuatu yang bermanfa'at untuk orang lain.

5) Bermain bersama anak. Selain sifat ingin didengar, anak-anak juga mempunyai kesenangan bermain. Bermain bersama anak merupakan salah satu media untuk pembelajaran. Karena dengan bermain bersama itu, orang tua mempunyai kesempatan untuk menyampaikan berbagai nasehat atau pengetahuan walaupun sifatnya yang 
ringan-ringan. Dengan demikian berarti orang tua telah menghargai anaknya dan mempunyai kepedulian terhadap sikap dan tingkah laku anaknya. Menghargai anak-anak dapat juga dilakukan dengan bahasa isyarat, misalnya mengangguk sebagai tanda senang dan membenarkan hasil kerja yang telah dilakukan anak. Penghargaan dengan katakata pujian atau sanjungan karena telah berhasil menyelesaikan suatu tugas atau berbuat kebaikan.

Sebagai sebuah cara dalam mendidik, penggunaan ganjaran atau penghargaan bukanlah hal yang mudah diterapkan. Karena itu dalam menerapkan penghargaan harus memperhatikan syarat-syarat tertentu yaitu:

1) Untuk memberi ganjaran yang bersifat mendidik, orang tua harus memahami betul karakteristik anaknya dan tahu menghargai dengan tepat. Sebab ganjaran atau penghargaan yang salah akan berakibat buruk bagi perkembangan psikis anak.

2) Apabila anak-anak yang akan diberi penghargaan atau ganjaran itu lebih dari seorang, maka diusahakan agar jangan menimbulkan rasa cemburu atau iri hati diantara anak-anak itu. Karena itu usahakan penghargaan itu tepat sesuai dengan karya prestasi anak.

3) Memberi penghargaan tidak secara terus menerus. Akan tetapi berilah penghargaan itu apabila dipandang sangat perlu dalam upaya mendorong peningkatan prestasi karya kebaikan. Sebab pemberian penghargaan yang terlalu sering akan menghilangkan hakikat dari penghargaan itu.

4) Hindari memberi ganjaran atau penghargaan dengan 
terlebih dahulu menjanjikan. Cara yang demikian itu akan menimbulkan kesulitan bagi orang tua dan akan berakibat anak-anak akan bekerja secara serampangan karena terburu-buru ingin mendapatkan penghargaan.

5) Orang tua harus berhati-hati dalam menerapkan penghargaan atau ganjaran. Sebab jangan sampai ganjaran itu dianggap oleh anak-anak sebagai upah atas upaya jerih payah yang ia lakukan. Hal ini akan menjadi tidak baik bagi perkembangan pendidikan anak-anak (Purwanto, 1995: 184).

Penghargaan yang kita berikan kepada anak-anak sangat penting bagi perkembangan pendidikan mereka. Berkaitan dengan hal tersebut Hurlock (1992, I: 90) mengatakan bahwa penghargaan itu mempunyai fungsi:

1) Sebagai nilai didik. Penghargaan yang diberikan kepada anak mengisyaratkan bahwa apa yang dilakukan anak itu adalah baik atau benar. Maka apabila penghargaan yang diberikan itu sesuai dengan kondisi anak, maka nilai pendidikannya akan mengalami peningkatan. Hal ini akan mendorong anak untuk belajar atau bekerja lebih keras untuk kemudian menghasilkan karya yang lebih baik lagi. Itulah makna nilai didik yang sesungguhnya ditimbulkan oleh penghargaan.

2) Sebagai motivasi untuk menanggulangi perilaku yang tidak setuju secara sosial. Persetujuan terhadap suatu nilai yang dinyatakan dengan penghargaan akan memperoleh reaksi positif dari anak-anak. Dimasa mendatang mereka akan berbuat lebih baik lagi, sehingga akan memperoleh penghargaan yang lebih banyak.

3) Untuk memperkuat perilaku yang disetujui secara sosial. Anak-anak akan merasa perbuatannya sangat 
menguntungkan ketika ia harus belajar berperilaku yang disetujui secara sosial. Dengan demikian penghargaan digunakan untuk membentuk asosiasi yang menyenangkan terhadap perilaku yang diinginkan anak.

Ada beberapa metode pendidikan yang menurut AnNahlawi (1979: 204-120) sangat efektif untuk membina kepribadian anak dan memotivasi mereka agar mampu memahami agama Islam serta dapat berkembang sesuai dengan karakternya masing-masing. Metode-metode tersebut dapat diterapkan dalam pendidikan keluarga muslim, sehingga memungkinkan keluarga-keluarga muslim membina anak-anak mereka menjadi generasi yang tangguh menghadapi masa depan. Metode-metode dimaksud adalah:

1) Metode Hiwar Qur'ani dan Nabawi. Hiwar (dialog) ialah percakapan antara dua orang atau lebih mengenai suatu masalah dengan sengaja diarahkan pada tujuan tertentu yang diinginkan. Dialog ini akan banyak memberikan manfa'at baik bagi kedua pihak yang melakukan dialog maupun pihak ketiga sebagai pendengar. Karena hiwar memiliki karakteristik: Pertama, dialog dilakukan secara dinamis karena kedua belah pihak yang berdialog saling terlibat secara intensif. Sebab apabila salah satu pihak kurang memperhatikan isi dialog maka dialog akan terganggu karena jalan pikiran salah satu pihak tidak dapat diikuti secara tuntas. Dengan cara ini kebenaran maupun kesalahan dari masing-masing pihak segera dapat diketahui dan secara cepat dapat direspon. Kedua, dialog ini menuntut para pendengar lebih tekun dan perhatian penuh, sehingga ia dapat mengetahui kesimpulan dari hasil dialog Dengan demikian dapat mengurangi rasa 
bosan dan jenuh. Ketiga, dialog dapat membangkitkan perasaan dan menimbulkan kesan yang mendalam dalam jiwa, sehingga membantu mengarahkan seseorang untuk memperoleh kesimpulan sendiri. Keempat, dialog yang dilakukan berdasarkan etika Islam, artinya peserta dialog saling menghormati, menghargai pikiran dan pendapat lawan, tidak emosional, tidak saling berlaku curang dan marah, maka proses dialog justru akan berdampak pada pencapaian tujuan pendidikan Islam, yaitu membentuk manusia berkepribadian muslim yang baik.

2) Hiwar qur'ani dan ta'abuddi, merupakan dialog yang diambil dari dialog antara Tuhan dengan hamba-Nya, sebagaimana tercermin dalam hadis Abu Hurairah yang merupakan dialog antara Allah dengan hamba-Nya, seperti dilukiskan dalam al-Qur'an surah al-Fatihah, bahwa apabila seorang hamba berkata: "Segala puji bagi Allah, Tuhan semesta alam, Allah SWT menjawab: hamba$\mathrm{Ku}$ telah memuji-Ku, Maha Pemurah lagi Maha Penyayang, Hamba-Ku telah memuja-Ku, jika seorang hamba berkata "yang menguasai hari Pembalasan" Allah menjawab: Hamba$\mathrm{Ku}$ memuliakan-Ku atau hamba-Ku menyerahkan semua urusan kepada-Ku, jika seorang hamba berkata: Hanya kepada Engkau kami menyembah dan meminta pertolongan, Allah menjawab: ini adalah antara Aku dengan hamba-Ku. Bagi hamba-Ku adalah apa yang dia minta. Apabila hamba berkata tunjukilah kami jalan yang lurus yaitu jalan orangorang yang telah Engkau anugrahkan nikmat dan bukan jalan orang-orang yang Engkau murkai dan tersesat. Allah menjawab ini adalah untuk hamba-Ku dan bagi hamba-Ku adalah apa yang dia minta. 
Adapun bentuk dialog khithabi yang penting untuk diketahui adalah:

1) Dialog yang diawali dengan seruan untuk mengenalkan keimanan atau diarahkan kepada orang-orang beriman. Dengan keimanan itu orang muslim akan bertanggung jawab untuk mengamalkannya dan dapat mengambil manfa'at dari amaliah tersebut. Dalam al-Qur'an Allah SWT menunjukkan berbagai bentuk ta'dif (pembebanan kewajiban dan larangan): Pertama, Bentuk penjelasanpenjelasan tentang hukum Allah agar diamalkan manusia, seperti hukum khamar, wudu', atau tayamum. Kedua, Berbentuk larangan terhadap perkara yang secara jelas diharamkan oleh syara' seperti judi, khamr, membunuh binatang buruan ketika ihram. Ketiga, Berbentuk dorongan untuk melakukan perkara-perkara besar yang hanya dapat dilakukan oleh orang-orang beriman, seperti kesabaran, ketakwaan, bertaubat dan berjihad.

2) Dialog yang bersifat peringatan terhadap nikmat-nikmat Allah melalui pengambilan pelajaran dari kelompok orangorang yang dihukum karena melanggar larangan Allah SWT. Ada pula peringatan agar selalu merenungi nikmat Allah " ...ingatlah akan nikmat Allah kepadamu ketika kamu dahulu bermusuh-musuhan, maka Allah mempersatukan hatimu, lalu menjadikan kamu karena nikmat Allah orang-orang yang bersaudara... (Q.S. Ali Imran: 103).

3) Dialog yang bersifat mengingatkan dan menjelaskan. Pertanyaan dan jawaban yang datang dari Allah merupakan bentuk dialog ini yang bertujuan untuk mengarahkan pola berpikir manusia kepada suatu pokok 
pembahasan agar menjadi jelas. Ayat-ayat yang menerangkan tentang bentuk dialog ini dapat dibaca dalam Q.S an-Naba': 1-3 dan Q.S al-Ghasiyah: 1-2. Diantara tujuan dialog yang bersifat peringatan ini adalah mengingatkan kepada manusia akan terjadinya hari qiamat sebagai sebuah masalah yang sangat besar, mengingatkan manusia pada kaidah-kaidah umum dan sunnah Ilahiah.

4) Dialog afektif yang bertumpu pada mengutamakan afeksi kemanusiaan dan afeksi pengalaman yang mampu mempengaruhi berperilaku baik dan beramal saleh, seperti rasa takut, harapan, kesenangan dan khawatir.

5) Dialog yang bersifat afektik dan reptetif. Dialog tersebut meliputi pengajuan pertanyaan tertentu secara berulangulang untuk mempertegas perasaan yang masih kabur.

6) Dialog khithabi yang bersifat sindiran. Melalui dialog ini Allah menyeru kaum musyrikin melalui Rasul SAW dengan sindiran atau ancaman atas keburukan, kebatilan dan kelemahan mereka. Hal itu dapat diketahui dalam ayatayat yang dilatar belakangi perlakuan batil kaum musyrikin seperti: Pertama, Ayat yang menunjukkan perlakuan batil kaum musyrikin terhadap Rasul SAW (QS. At-Thur: 29). Kedua, Ayat yang menunjukkan ancaman Allah (QS. alQalam: 44-45).

7) Dialog Deskriptif. Dialog deskriptif adalah suatu dialog yang berusaha mendeskripsikan kondisi hidup dan psikologis orang-orang yang terlibat dalam dialog. Dengan demikian dapat dipahami tentang kebaikan maupun keburukan yang ada pada orang tersebut dan akan mempengaruhi mentalitas seseorang yang mampu 
mengembangkan perasaan ketuhanan dan perilaku yang baik manusia. Dalam al-Qur'an banyak ayat yang menggambarkan bagaimana dialog deskriptif ini dilakukan sebagaimana terdapat dalam surah ash-Shaff: 20-23. Kisah dalam ayat tersebut menggambarkan bahwa orang-orang yang zalim menyadari akan kebangkitan kubur dan mereka tengah menghadapi hari qiamat.

8) Dialog Naratif. Dialog naratif adalah jenis dialog yang bersifat menguraikan suatu persoalan dihadapan lawan dialog. Dialog naratif dapat dilihat dalam al-Qur'an surah Hud ayat 85-95 yang mengisahkan Nabi Syu'aib dan kaumnya. Dialog naratif mampu memberikan pengaruh yang sangat menakjubkan. Selain dapat mempengaruhi penalaran, juga mampu mempengaruhi mentalitas dan perasaan seseorang.

9) Dialog Argumentatif. Dalam dialog argumentatif akan terjadi diskusi dan perdebatan untuk memperkokoh alasan agar kaum musyrikin mengakui pentingnya meng-Esakan Allah SWT, mengakui kerasulan Muhammad SAW dan kebenaran seruan Nabi serta mengakui kebatilan tuhan-tuhan mereka. Sebagaimana digambarkan dalam al-Qur'an surah an-Najm: 1-18. Dalam bentuk yang lain dialog argumentatif disajikan melalui pertanyaan-pertanyaan yang mengingkari tuhan-tuhan kaum musyrikin. Sebagaimana dapat diketahui penjelasan Allah dalam alQur'an surah an-Najm: 119-20. Dialog naratif mampu membina akal manusia agar berpikir sehat untuk mencapai kebenaran melalui metode konklusi (penyimpulan), metode analogi yang sahih dan metode berpikir yang topikal, realistis dan penarikan argumentasi 
dari hal-hal yang konkrit untuk yang memecahkan tuntutan akan hal-hal gaib.

10) Dialog Nabawi. Dialog Nabawi adalah cara mendidik dan mengajar yang diterapkan Rasul SAW kepada para sahabatnya. Sikap para sahabat yang paling disukai oleh Rasul SAW adalah mengajukan suatu pertanyaan kepada Rasul SAW. Oleh karena itu Rasul SAW menganjurkan kepada para sahabat agar selalu bertanya tentang segala hal untuk kemudian dijawab, sehingga memperluas wawasan dan pengetahuan. Metode dialog Nabawi yang mempu menyentuh perasaan itu akan membawa kepada pemahaman yang benar tentang agama yaitu: Pertama, pendidikan yang benar dan mendalam untuk membina perasaan ketuhanan merupakan cara untuk meneguhkan perasaan tersebut dalam keadaan bagaimanapun. Kedua, untuk mengobarkan perasaan ketuhanan itu Rasul SAW menggunakan metode al-Qur'an yang interogatif. Nabi seolaholah bertindak sebagai pemandu Ilahi untuk memahami surah Adh-Dhuha, " Bukankah dahulu aku datang kepada kamu, sedang kamu dalam keadaan sesat, lalu Allah menunjuki kamu, sedang kamu dalam keadaan miskin, lalu Allah memberi kamu karunia, sedang kamu dalam keadaan bermusuhan.

e. Metode Kisah Qur'ani dan Nabawi.

Al-Qashshu atau al-Qishshatu yang berarti cerita (Munawir, 1984: 1210), yang semakna dengan tadabbu'ul atsran, yaitu pengulangan kembali keadaan masa lalu (Al-Utsaimin, tt: 70). Kata Al-Qasas adalah bentuk masdar sebagaimana firman Allah "fartadda 'ala atsarihima gashasha" lalu keduanya kembali mengikuti jejak mereka semula (Q.S. 18: 64). Qasas al-Qur'an 
adalah pemberitaan al-Qur'an tentang keadaan umat terdahulu, nubuat (kenabian) terdahulu dan peristiwa-peristiwa yang telah terjadi (Al-Qattan, 2000: 436). Dengan membaca kisah al-Qur'an kita akan banyak memperoleh manfa'at atau faedah bagi peningkatan keimanan kepada Allah SWT.

Beberapa faedah yang terpenting menurut Al-Qattan (2000: 437) adalah: Pertama, menjelaskan azas-azas dakwah menuju kepada Allah dan menjelaskan pokok-pokok syari'at yang dibawa oleh para nabi. Kedua, meneguhkan hati Rasul SAW dan hati umat Muhammad atas agama Allah, memperkuat kepercayaan orang Islam terhadap kebenaran yang akan mengalahkan kebatilan. Ketiga, membenarkan para nabi terdahulu, menghidupkan kenangan terhadap mereka serta mengabadikan jejak dan peninggalannya. Keempat, menunjukan kebenaran dakwah Rasul SAW tentang keadaan umat terdahulu. Kelima, menyibak kebohongan ahli kitab dan menentangkan mereka dengan kitab mereka sendiri. Keenam, kisah merupakan bentuk sastra yang mampu menarik perhatian para pendengar dan memantapkan pesan yang terkandung di dalamnya ke dalam jiwa manusia.

Kisah-kisah al-Qur'an mengandung tujuan pendidikan yang sangat penting. Oleh karena itu, ia menjadi salah satu metode dalam pendidikan Islam. Tujuan terpenting itu adalah: Pertama, untuk mengokohkan adanya wahyu dan kerasulan nabi Muhammad SAW. Artinya bahwa Nabi Muhammad SAW tidak pernah belajar kepada pendeta Yahudi dan Nasrani di sa'at beliau harus membacakan kisah-kisah tersebut kepada kaumnya. Kisah-kisah al-Qur'an sangat rinci dan jelas sehingga tidak menimbulkan keraguan bagi orang-orang yang menggunakan akalnya, di peroleh Nabi SAW dari firman Allah 
SWT. Jadi Nabi hanya menyampaikan kisah tersebut kepada kaumnya, sebagaimana dapat dibaca dalam Q.S Yusuf: 2-3 dan Q.S Hud: 49. Kedua, kisah-kisah al-Qur'an merupakan penjelasan bahwa seluruh agama yang dibawa oleh para nabi berasal dari Allah SWT. Ketiga, kisah al-Qur'an merupakan penjelasan bahwa Allah adalah penolong para Rasul dan orangorang beriman, mengasihi dan menyelamatkan mereka dari berbagai bencana sejak dari zaman Adam sampai zaman Muhammad SAW sebagaimana dapat dibaca dalam Q.S alAnbiyaa: 87-92. Tujuan utama penyajian kisah Al-Qur'an adalah untuk menunjukkan bahwa seluruh nabi menganut agama yang satu; mereka tunduk kepada Tuhan yang satu dan hanya beribadah kepada Allah SWT, tidak ada sekutu bagi Allah SWT. Keempat, untuk menghibur kebingunngan hati kaum muslimin melalui penggambaran kokohnya keimanan Rasul SAW dan pengikutnya, serta mampu memberikan sugesti yang besar kepada orang-orang yang cenderung pada keimanan sebagaimana dapat dibaca dalam Q. S Hud: 120, Al-Ankabut: 40. Kelima, mengingatkan kepada manusia akan perilaku syetan yang membahayakan manusia sehingga manusia harus mewaspadai bisikan yang dapat menjerumuskan manusia kepada kejahatan. Kisah al-Qur'an mampu menjelaskan secara rinci kekuasaan Allah sehingga mempengaruhi emosi yang dapat menimbulkan rasa khusu', ketundukan dan kepasrahan kepada Allah SWT. (An-Nahlawi, 1995: 243-247). Keenam, menerangkan bahwa semua agama itu dasarnya satu dan semuanya dari Tuhan Yang Maha Esa (Q.S. al-'Araf: 59) dan menerangkan bahwa cara yang ditempuh oleh para nabi dalam berdakwah sama, sehingga sambutan dari para kaumnya menyambut dakwah itu juga serupa. 
Ketujuh, menerangkan dasar yang sama antara agama yang diajarkan Nabi Muhammad dengan agama yang dibawakan oleh Nabi Ibrahim as secara khusus dan dengan agama-agama bangsa Israil pada umumnya dan menjelaskan bahwa hubungan ini lebih erat dari pada hubungan yang umumnya dilakukan antara semua agama, Keterangan ini secara berulang-ulang dikisahkan dalam cerita Nabi Ibrahim, Musa dan Isa as (Qutb dalam Chirzin, 2003: 61).

Kisah-kisah Nabawi juga mengandung tujuan pendidikan antara lain: Pertama, dalam kisah Nabawi kita akan menemukan ajaran keikhlasan dalam beramal saleh dan menjadikannya sebagai sarana mencapai keredaan Allah dalam memecahkan berbagai permasalahan hidup, sebagaimana kisah tiga orang pejalan kaki yang tertutup gua (H. R Al-Bukhari dan Muslim), Kedua, kisah yang mengarahkan kita pada kebiasaan bersedekah, seperti kisah orang bermata satu, berpenyakit kusta dan orang buta. Ketiga, kisah-kisah yang bersifat historis, kisah historis yang menyempurnakan, menjelaskan dan memperluaskan isyarat-isyarat al-Qur'an melalui kisahkisah yang singkat, kisah-kisah yang tidak langsung berasal dari Rasul SAW dan kisah-kisah yang berhubugan dengan peristiwaperistiwa sejarah dan peperangan yang dilakukan Rasul SAW.

Dalam pendidikan keluarga metode kisah ini sering digunakan terutama oleh orang-orang tua atau kakek-nenek dikampung-kampung atau yang sering disebut mendongeng, ketika anak atau cucu akan memulai tidur, seperti mengisahkan hikayat Malinkundang, cerita orang-orang saleh dan lain-lain.

f. Metode perumpamaan

Secara bahasa kata matsal dan mitsil yang jamaknya amsal berarti, misal, perumpamaan, sesuatu 
yang menyerupai (Yunus, 1990: 410). Pengertian menurut istilah sebagai mana Ibnul Qayyim yang dikutip Al-Qattan mendefinisikan amtsal Qur'an dengan menyerupakan sesuatu dengan sesuatu yang lain dalam hal hukumnya dan mendekatkan sesuatu yang abstrak dengan yang konkrit. Amtsal dalam Al-Qur'an dapat didefinisikan dengan menonjolkan makna dalam bentuk perkataan yang menarik, padat dan yang mempengaruhi secara mendalam terhadap jiwa seseorang (Al-Qattan, 2000: 403).

Di dalam Al-Qur'an dikenal ada tiga macam amtsal (AlQattan, 2000: 405-407), yaitu: Pertama, amtsal musarrahah ialah amtsal yang dijelaskan dengan lafaz masal atau sesuatu yang menunjukkan tasybih. Amtsal yang demikian ini banyak ditemukan dalam Al-Qur'an diantaranya adalah "perumpamaan (masal) mereka adalah seperti orang yang menyalakan api, maka setelah api itu menerangi sekelilingnya, Allah menghilangkan cahaya (yang menyinari) mereka dan membiarkan mereka dalam kegelapan, tidak dapat melihat. Mereka tuli, bisu dan buta, maka tidaklah mereka akan kembali ke jalan yang benar atau seperti orang-orang yang ditimpa (hujan) lebat dari langit disertai gelap gulita, guruh dan kilat..(Q. S. Al-Baqarah: 17-20). Kedua, amtsal kaminah yaitu amtsal yang di dalamnya tidak disebutkan dengan jelas lafaz tamsil, tetapi ia menunjukkan makna-makna yang indah dan menarik dalam kepadatan redaksinya dan mempunyai pengaruh tersendiri apabila dipindahkan kepada yang serupa dengannya. Contoh yang dapat dikemukakan antara lain: Ayat-ayat yang senada dengan perkataan "Khairul umuril wasthu"(sebaik-baik urusan adalah pertengahannya) seperti mengenai sapi betina " Sapi betina yang tidak tua dan tidak 
muda; pertengahan diantara itu.. (Q.S Al-Baqarah: 68). Ketiga, amtsal mursalah, yaitu kalimat-kalimat bebas yang tidak menggunakan lafaz tasybih secara jelas, tetapi kalimat itu berlaku sebagai masal. Beberapa contoh dapat dikemukakan adalah: sekarang ini jelas kebenaran itu (Q.S.Yusuf: 51), tidak ada yang akan menyatakan terjadinya hari itu selain Allah swt (Q.S. An-Najm: 58), telah diputuskan perkara yang kamu berdua menanyakannya kepadaku (Q. S.Yusuf: 41) dan lain sebagainya.

Banyak manfa'at amtsal bagi kepentingan pendidikan karena amtsal menjadi salah satu cara dalam mendidik. Diantara manfa'at amtsal itu (Al-Qattan, 2000: 409-412 dan Hizrin, 2003: 69-70) adalah: Pertama, menonjolkan sesuatu yang ma'qul (yang hanya dapat dijangkau oleh akal, abstrak) dalam bentuk yang konkrit yang dapat dirasakan oleh indra manusia, sehingga dapat diterima akal. Sebab pengertian yang abstrak tidak akan tertanam dalam pikiran kecuali dituangkan melalui bentuk nyata yang dapat di indrawi yang mudah dipahami oleh akal. Kedua, menyingkapkan hakikat-hakikat dan mengemukakan sesuatu yang tidak tampak menjadi seolah-olah tampak sesuatu yang tampak misalnya dalam Q.S. Al-Baqarah: 275. Ketiga, mengumpulkan makna yang menarik lagi indah dalam ungkapan yang padat seperti amtsal kaminah, amtsal mursalah dalam contoh ayat yang telah dikemukankan. Keempat, mendorong orang yang diberi amtsal untuk berbuat sesuai dengan isi matsal, jika ia merupakan sesuatu yang disenangi jiwa. Misalnya orang yang menafkahkan harta di jalan Allah ia akan memberikan kepadanya kebaikan yang banyak (Q.S. Al-Baqarah: 261). Kelima, untuk menjauhkan apabila isi amtsal berupa sesuatu yang dibenci jiwa. Misalnya tentang larangan bergunjing oleh 
sebagian orang terhadap yang lainnya karena menggunjing itu disamakan dengan memakan daging sesama saudara (Q.S. Al-Hujurat: 12). Keenam, untuk memuji orang yang diberi amtsal. Ketujuh, untuk menggambarkan sesuatu yang mempunyai sifat yang dipandang buruk oleh orang banyak misalnya tentang keadaan orang yang dikarunia kitabullah, tetapi ia tersesat sehingga tidak mengamalkannya. Kedelapan, amtsal lebih berpengaruh pada jiwa, lebih efektif dalam memberikan nasehat, lebih kuat dalam memberikan peringatan dan lebih dapat memuaskan hati. Misalnya Allah telah banyak membuat perumpamaan bagi manusia supaya mereka mendapat pelajaran (Q.S. Az-Zumar: 43).

Perumpamaan yang terkandung dalam Al-Qur'an mempunyai tujuan: Pertama, menyerupakan suatu perkara yang akan dijelaskan kebaikan dan keburukannya dengan perkataan lain yang sudah diketahui secara umum tentang kebaikan dan keburukannya, seperti menyerupakan kaum musyrikin yang mengambil perlindungan selain Allah dengan sarang laba-laba yang rapuh dan lemah. Kedua, menceritakan berbagai keadaan dan membandingkan keadaan itu dengan keadaan lain yang sama-sama memiliki akibat. Pengungkapan itu untuk menujukkan perbedaan yang terdapat dalam kedua keadaan tersebut, sebagaimana di jelaskan dalam Al-Qur'an "Allah menghapus perbuatan orangorang kafir yang menghalangi manusia dari jalan Allah, sedangkan orang-orang yang beriman dan mengerjakan amal-amal saleh, Allah menghapuskan kesalahan-kesalahan mereka dan memperbaiki keadaan mereka. Yang demikian itu karena orang-orang kafir mengikuti yang batil dan orang-orang 
beriman mengikuti yang hak" (Q.S. Muhammad: 1-3). Ketiga, menjelaskan kemustahilan terdapatnya persamaan diantara dua perkara seperti kemustahilan anggapan kaum musyrikin bahwa tuhan mereka memiliki kesamaan dengan Allah swt sehingga mereka menyembah keduanya secara bersamaan. Allah membuat perumpamaan bahwa segala sesuatu yang diseru selain Allah tidak mampu menciptakan seekor lalatpun (Q.S. Al-Hajj : 73).

Demikianlah perumpamaan ini dapat digunakan sebagai cara untuk mendidik anak-anak dengan berbagai materi, misalnya mengumpamakan orang yang rajin salat dengan orang yang malas salat. Orang yang rajin salat dengan terlebih dahulu berwudu seperti orang yang mandi lima kali dalam sehari sehingga bersih badannya dan sehat tubuhnya.

g. 'Ibrah dan Mau'izhah

'Ibrah berasal dari kata 'abra ar-ru'ya yang berarti menafsirkan mimpi dan memberitahukan implikasinya bagi kehidupan orang yang bermimpi. Ar-Raqhib berkata bahwa asal makna kata al-ibr adalah melintasi suatu keadaan kepada keadaan lain dan kata 'ubur dikhususkan untuk makna "melintas diatas air". Muhammad Rasyid Ridha dalam menafsirkan surat Yusuf mengatakan bahwa al- 'itibar wal 'ibrah berarti keadaan yang mengantarkan dari suatu pengetahuan yang terlihat menuju suatu yang tidak terlihat atau dengan kata lain berarti merenung dan berpikir (AnNahlawi, 279).

Dengan demikian 'ibrah dan 'itibar itu merupakan kondisi psikologis yang mampu mengantarkan manusia menuju pengetahuan. 'Ibrah yang terkandung dalam AlQur'an mengadung dampak pendidikan yang sangat besar 
yaitu mengantarkan seseorang untuk memperoleh kepuasan berpikir tentang akidah, dapat menggerakkan hati, mengembangkan perasaan ketuhanan, dan mengokohkan ketundukan kepada syariat yang diperintahkan Allah swt. Mau'izhah berasal dari kata wa'dza-ya'dzu-wa'dzan-'idzatan yang berarti nasehat, bimbingan, pendidikan dan peringatan (Makluf, 1986: 907). Mau'idzah menurut Imam Abdullah bin Ahmad an-Nasafi dalam Hasanuddin (1996: 37) adalah perkataan-perkataan yang tidak tersembunyi bahwa engkau memberikan nasihat dan menghendaki manfa'at kepada mereka dengan Al-Qur'an. Dengan demikian ada kesamaan antara mau'idzah dengan 'ibrah yaitu sama-sama mengandung makna pendidikan atau pengajaran, sehingga dalam bagian ini dimaksudkan sebagai cara mendidik atau mengajarkan orang lain.

Dalam Al-Qur'an dan As-Sunnah terdapat beberapa jenis 'ibrah yaitu: Pertama, 'ibrah melalui kisah. Setiap kisah AlQur'an atau Nabawi mempunyai tujuan pendidikan. 'Ibrah melalui kisah hanya dapat dicapai oleh orang yang berpikir. Artinya ia mampu mengambil kesimpulan dari suatu kisah. Sesungguhnya dalam kisah itu terdapat pelajaran bagi orangorang yang mempunyai akal atau menggunakan akalnya" (Q.S.Yusuf: 111) . Pelajaran yang dapat diperoleh dari kisah Nabi Yusuf adalah kekuasaan Allah menyelamatkan Yusuf setelah dilemparkan ke dalam jurang sumur. Kedua, mengambil pelajaran dari nikmat dan makhluk Allah. Banyak nikmat yang disediakan Allah bagi manusia dan banyak pula makhluk Allah yang dapat dijadikan 'ibrah bagi manusia. Sesungguhnya pada binatang ternak itu benarbenar terdapat pelajaran bagi manusia. Allah memberi 
manusia minuman (susu) yang berasal dari perut binatang yang bersih antara tinja dan darahnya, yang mudah ditelan bagi orang-orang yang meminumnya (Q.S An-Nahl: 66). Sesungguhnya pada binatang ternak yaitu sapi, unta dan domba benar-benar terdapat pelajaran yaitu tanda kekuasaan yang menunjukan kepada hikmah dari penciptaan-Nya, rahmat-Nya, dan kasih sayang-Nya. Susu yang bersih antara tahi dan darah yakni warna putih susu, rasa manisnya terpisah dari kotoran dan darah di dalam perut binatang. Masing-masing mengalir ke tempatnya sendiri. Jika makanan telah dicerna dalam perut, maka darah mengalir ke urat, susu mengalir ke lambung, air seni mengalir ke kemih dan kotoran ke dubur. Masing-masing tidak bercampur dengan yang lain dan tidak mempengaruhinya setelah terpisah (Ar-Rifa'i, 1989, 2: 1041). Dan dari buah kurma dan anggur kamu buat minuman yang memabukkan dan rizki yang baik. Sesungguhnya pada yang demikian itu benar-benar terdapat tanda (kebesaran Allah) bagi orang-orang yang memikirkan (Q.S An-Nahl: 67). Ketiga, mengambil pelajaran dari peristiwa sejarah. Pelajaran yang dapat diambil dari peristiwa perang Badar dan ahzab, bahwa tentara Islam mempu mengalahkan tentara kaum Kafir walaupun jumlah tentara kaum muslimin jauh lebih sedikit dari kaum kafir. Hal ini menunjukkan kekuasaan dan kekuatan Allah di atas segalanya dan pertolongan Allah kepada kaum muslimin, sehingga mampu mengalahkan kaum kafir.

Oleh karena itu menurut An-Nahlawi (1995: 285) kita akan memperoleh pelajaran dan mengetahui tujuan dibalik suatu peristiwa sejarah yaitu: Pertama, memahami sunnatullah bahwa orang-orang yang berbuat kerusakan dan 
zalim akan musnah dan membiarkan orang saleh hidup "Allah telah mengazab negeri-negeri yang penduduknya berbuat zalim dengan azab yang sangat pedih lagi keras dan tidak akan membinasakan negeri yang penduduknya orang-orang yang berbuat kebaikan (Q.S. Hud: 117). Kedua, memahami bahwa taubat dan penyesalan tidak berguna apabila telah terjadi kebinasaan "Ketika azab Allah telah menimpa kaum kafir mereka berkata bahwa mereka beriman kepada Allah dan mengingkari terhadap sesembahan yang mereka buat. Akan tetapi iman mereka tidak berguna. Karena itu adalah sunnah Allah yang telah berlaku dan binasalah kaum kafir (Q.S. AlMu'min: 84-85). Ketiga, memahami sunnah Allah dalam membenkan pertolongan kepada hamba-hamba-Nya yang beriman dan mengamalkan syari'at-Nya. Sekiranya orangorang kafir itu memerangi kamu pastilah mereka kalah kemudian mereka tidak memperoleh pertolongan dan perlindungan. Karena itu merupakan sunnah Allah yang berlaku sejak dahulu dan tidak ada perubahan terhadap sunnatullah (Al-Fath: 22-23). Keempat, memahami sunnatullah dalam pembinasaan orang-orang munafik yang menghancurkan masyarakat, menimbulkan fitnah dan menyebarluaskan kebohongan untuk menimbulkan huru hara di kalangan kaum muslimin," Sesungguhnya jika orang-orang munafik tidak berhenti menyakitimu, niscaya Kami perintahkan kamu memerangi mereka, kemudian mereka tidak menjadi tetanggamu, melainkan dalam waktu sebentar dan dalam keadaan terlaknat. Mereka akan ditangkap dan dibunuh. Demikianlah sunnatullah berlaku terhadap orangorang terdahulu (Q.S. Al-Ahzab: 60-62). Kelima, untuk memahami bahwa seringkali orang kaya, para pemimpin 
dan orang-orang yang suka bermewah-mewah menjadi sebab kebinasaan umatnya, durhaka kepada Allah dan mengabaikan syari'at serta dibiarkan oleh para ulama. "Apabila Kami hendak membinasakan suatu negeri, maka Kami perintahkan kepada orang-orang yang hidup mewah dinegeri itu supaya menta'ati Allah, tetapi mereka melakukan kedurhakaan, maka sudah sepantasnya berlaku terhadap mereka ketentuan Allah. Kemudian Allah hancurkan negeri itu dengan kehancuran yang hebat. (Q.SAl-Isra':16).

Pengajaran sejarah menurut An-Nahlawi (1985: 287289) mempunyai tujuan : Pertama, mengambil ibrah dari peristiwa sejarah. Kedua, meneliti perwujudan sunnatullah yang terjadi pada umat terdahulu dan bagaimana Allah menggilirkan kejadian di antara manusia. Ketiga, meneliti dampak berbagai peristiwa sejarah terhadap kebaikan umat manusia. Keempat, meneliti hikmah dan pengaturan Allah ketika Dia membinasakan orang-orang zalim untuk menghibur kaum muslimin yang dizalimi, "Dan sekiranya Allah tidak menolak keganasan sebagian manusia terhadap sebagian yang lainnya, tentulah telah dirobohkan biara-biara Nasrani, gereja-gereja, rumah-rumah ibadah orang-orang Yahudi dan masjid-masjid yang di dalamnya banyak disebut nama Allah. Sesungguhnya Allah pasti menolong orang yang menolong agama-Nya (Q.S. Al-Haj: 40). Kelima, mengetahui bahwa tujuan sebuah kemenangan dan kekokohan dibumi adalah untuk menegakkan syari'at Allah, mewujudkan perdamaian dan menghapus kerusakan" orang-orang yang diteguhkan kedudukannya niscaya mereka mendirikan salat, menunaikan zalat, menyuruh berbuat makruf dan mencegah perbuatan mungkar (Q.S. Al-Haj: 41). Keenam, setiap anak 
harus mampu mengaplikasikan sunnah-sunnah Allah ke dalam perkembangan sejarah dan peristiwa yang sedang mereka pelajari. Ketujuh, pengajaran sejarah itu harus menjadi sarana untuk menanamkan akidah dan mengokohkannya sehingga anak-anak akan memahami bahwa alam semesta yang mengagumkan ini mesti ada yang menciptakannya.

h. Metode melalui Aplikasi dan Pengamalan

Metode aplikasi dan pengamalan adalah cara mengajar suatu pengetahuan melalui pelaksanaan dari sebuah teori ke dalam praktek atau pengamalan konkrit. Metode praktek dan latihan atau pengamalan ini dapat menimbulkan sikap kerja yang produktif dan membentuk kemampuan keterampilan. Oleh karena itu pengaruh praktek dan latihan itu dapat diketahui: Pertama, kesempurnaan kerja dapat dijadikan tolak ukur untuk memantau hafalan dan pengamalan ibadah. Kedua, membentuk manusia bertanggung jawab agar bekerja dengan baik. Ketiga, menghindari sifat malas bekerja serta mencintai amal saleh. Keempat, memiliki batasbatas kepuasan dan keinginan. Oleh karena itu Rasul saw mendidik para sahabat agar meninggalkan kebiasaan meminta-minta melalui penanaman rasa percaya diri untuk mencari rizki.

i. Metode Tarhgib dan Tarhib

Tarqhib adalah janji yang disertai bujukan dan rayuan untuk menunda kemaslahatan, kelezatan dan kenikmatan yang dilaksanakan melalui amal saleh dan pencegahan dari kelezatan yang membahayakan yang dilakukan untuk mencari reda Allah. Sedangkan tarhib adalah ancaman atau intimidasi melalui hukuman yang 
disebabkan oleh kesalahan, karena melanggar larangan Allah dan menganggap sepele pelaksanaan kewajiban yang diperintahkan Allah. Tarhib juga berarti ancaman untuk menakut-nakuti seseorang. Dengan demikian tarhib dapat disamakan dengan kata tanzir yang secara bahasa berarti suatu kata yang menunjukkan untuk penakutan (Suparta, 2003: 269). Kata tanzir dapat ditemukan dalam firman Allah "Sesungguhnya Kami telah mengutusmu (Muhammad) dengan kebenaran, sebagai pembawa berita gembira dan memberi peringatan (tanzir) dan kamu tidak diminta pertanggung jawaban tentang penghuni-penghuni neraka (Q.S.Al-Baqarah: 119). Tanzir itu merupakan ungkapan yang mengandung peringatan kepada orang yang berbuat kesalahan atau orang yang tidak beriman atau untuk melakukan tindakan preventif terhadap seseorang. Karena itu metode ini tepat juga digunakan untuk pendidikan keluarga.

Ada empat keistimewaan targhib dan tarhib: Pertama, tarqhib-tarhib Qur'ani dan Nabawi bertumpu pada pemberian kepuasan dan argumentasi. Kedua, Targhib dan Tarhib Qur'ani dan Nabawi disertai oleh gambaran keindahan dan kenikmatan surga yang menakjubkan atau pembeberan siksa neraka yang menyakitkan. Ketiga, Targhib-tarhib Qur'ani dan Nabawi bertumpu pada pengobaran emosi dan pembinaan afeksi ketuhanan. Metode pendidikan yang mentalistik ini adalah salah satu tujuan ditetapkannya syari'at Islam. Keempat, metode targhib dan tarhib bertumpu pada pengontrolan emosi, afeksi dan keseimbangan antara keduanya. Dengan demikian rasa takut tidak boleh menghilangkan harapan yang dapat mengakibatkan rasa putus asa dari rahmat Allah. "Orang 
berbuat melampaui batas diingatkan oleh Allah supaya jangan berputus asa dari rahmat Allah karena Allah mengampuni dosa mereka".(Q.S. Az-Zumar: 53). Bagi manusia yang imannya tidak kuat akan cenderung berputus asa manakala tertimpa musibah, sekalipun mereka berdo'a secara terus menerus (Q.S. Fushilat: 49). Keputus-asaan manusia merupakan perbuatan yang tidak disenangi Allah karena sifat tersebut dapat menjerumuskan manusia kepada kekafiran (mengingkari kekuasaan Allah). Oleh karena itu, Allah memadamkan rasa putus asa itu dengan kenikmatan dan kebahagiaan. "Ketika manusia diberi rahmat oleh Allah kemudian rahmat itu dicabut dari dirinya, pastilah manusia menjadi putus asa dan tidak berterima kasih. Akan tetapi ketika Allah mengganti suatu bencana dengan kesenangan dan yang membahagiakan, maka manusia berkata telah hilang bencana yang menimpa kami sehingga manusia sangat gembira dan bangga (Q.S. Hud: 9-11).

Di dalam Al-Qur'an banyak dijumpai cara mendidik dengan menggunakan targhib dan tarhib. Menurut Muhammad Ghazali (Hasymi, 240-245) ada lima uslub mendidik dengan targhib dan tarhib yaitu: Pertama, meminta keta'atan. Anak didik diminta untuk mena'ati perintah Allah karena Dialah yang patut dita'ati, Dia yang telah memberikan segala yang kita butuhkan. Kedua, menuntut agar berakhlak mulia. Kita kadang-kadang menuntut agar anak-anak berakhlak mulia, berbudi luhur, agar melaksanakan keadilan. Hal ini dilakukan karena semua perbuatan itu adalah baik yang diperintahkan Allah swt sebab Allah tidak menyuruh kecuali yang baik. Allah menyuruh menyampaikan amanat kepada ahlinya, 
melaksanakan hukum dengan adil, karena Allah mengajar sesuatu yang paling baik bagi manusia (Q.S. An-Nisa': 59). Ketiga, penghasungan bertaqwa. Kadang-kadang menggunakan cara menghasung anak agar bertakwa kepada Allah, bergegas menegakkan hak-hak-Nya dan menjaga batasbatas larangan-Nya, memenuhi kerelaan-Nya terhadap segala yang diminta-Nya. Keempat, Menggemarkan beriman dan beramal saleh. Manusia mempunyai karakter ingin memperoleh keuntungan yang sebanyak-banyaknya dan secepat-cepatnya. Oleh karena itu, perlu digemarkan agar beramal saleh supaya hasil amal saleh itu bisa segera diperoleh. Dorongan agar gemar beramal saleh digambarkan Allah dalam Al-Qur'an. "Allah akan menurunkan hujan untuk manusia, membantu dangan harta dan anak, akan memberikan kebun-kebun dan mengalirkan sungai-sungai untuk manusia (Q.S.Nuh: 7-12). Kelima, Pendorongan agar sabar menanti. Kadang-kadang anak didorong agar sabar menderita dalam mencari ilmu dan kesulitan menegakkan kebenaran, sanggup memikul tugas berat dengan akan adanya imbalan pahala besar yang diharapkan.

Sedangkan cara mendidik dengan menggunakan tarhib atau penakutan menurut Muhammad Ghazali dengan lima cara yaitu:

1) Penyebutan nama Allah. Menyebutkan nama Allah akan mempengaruhi seseorang agar mengikuti apa yang kita didikkan kepada mereka. Karena menyebut nama Allah itu akan menggerakkan jiwanya untuk mengamalkan suatu perbuatan baik yang diajarkan dan bahkan meninggalkan perbuatan buruk yang dilarang. "Ketika disebut nama Allah hati bergetar (Q.S. Al-Anfal: 3). Hati bergetar untuk segera 
mengingat Allah dan meninggalkan larangan-Nya.

2) Menampilkan kemesuman. Untuk mendidik dapat pula diupayakan dengan menampilkan kejelekan, kekotoran dan kemesuman dari perbuatan jahat itu. Karena itulah Islam menyebut kema'siatan itu sebagai kotoran dan kemesuman yang menjijikkan fitrah manusia yang sehat untuk mendekatinya.

3) Mengungkapkan bahayanya. Agar orang tidak berbuat dosa dan melaksanakan kebaikan maka dapat diupayakan dengan mengungkapkan bahaya dosa itu. Dengan demikian diharapkan setelah memahami dosa sebagai akibat suatu perbuatan jahat orang akan berpikir ulang untuk melakukannya."Orang-orang jahat melihat dosanya seperti lalat yang bertengger di puncak hidungnya, lalu mengatakan kepadanya begitu saja, maka terbanglah ia (Al-Hadis).

4) Menegaskan akan datang bahaya. Untuk mendidik agar seseorang melaksanakan apa yang kita didikkan dan apa yang dilarang kepada seseorang dapat diupayakan dengan menegaskan akan segera datang bahaya atau bencana yang akan menimpa seseorang, keluarga maupun masyarakatnya. Dengan cara tersebut diharapkan niat seseorang untuk melakukan kejahatan segera diurungnya dan segera bertaubat kepada Allah. Dalam hadis dari Ibnu Umar ra Rasul saw bersabda kepada orang-orang Muhajirin, bahwa ada lima perkara yang apabila menimpa mereka maka akan membinasakan mereka dan Nabi berdo'a agar bahaya tersebut tidak menimpa mereka". Pertama, Apabila kejahatan telah berkembang dalam lingkungan suatu 
kaum maka akan berkembang biak kelaparan. Kedua, Urusan timbangan dan ukuran akan menimbulkan krisis ekonomi dan krisis kekuasaan. Ketiga, Mereka yang menahan zakat hartanya pada hakikatnya menahan turunnya hujan dari langit, seandainya tidak ada ternak dibumi pasti langit akan mencurahkan hujan lagi. Keempat, Orang yang memutuskan hubungan dengan Allah dan Rasul saw akan jatuh dalam perangkap musuh dan akan hilang sebagian hartanya. Kelima, Pemimpin yang tidak menggunakan Al-Qur'an sebagai dasar hukumnya akan selalu menjadi perebutan kekuasaan sesama mereka.

5) Menyebutkan peristiwa akhirat. Untuk mendidik orang lain agar melaksanakan perintah Allah dan melakukan berbagai kebaikan, kadang-kadang kita harus menyebut peristiwa akhirat, seperti azab neraka yang amat dahsyat. "Seorang wanita akan masuk neraka karena tidak memberi makan seekor kucing dan tidak juga melepasnya.

\section{KESIMPULAN}

Keluarga adalah institusi pertama dan terkecil yang ada dalam suatu masyarakat dimana terjadi hubungan-hubungan antar anggota keluarga atau hubungan antar keluarga dengan keluarga lainnya dalam suatu masyarakat. Pendidikan keluarga adalah sebuah upaya yang dilakukan oleh orang tua secara terencana untuk mengembangkan akal, perasaan dan perilaku anak-anak yang didasarkan atas ajaran Islam, sehingga terbentuk anak saleh-salehah yang dapat mewujudkan tujuan agama Islam dalam seluruh segi kehidupan manusia. 
Syaiful Anam : Pendidikan Pesantren Sebagai Model Yang Ideal Dalam Pendidikan Islam

Tujuan pendidikan keluarga adalah agar anak mampu berkembang secara maksimal seluruh aspek perkembangan anak, baik jasmani, ruhani maupun akal dan juga untuk membantu sekolah dalam mengembangkan kepribadian anak didik. Adapun metode pendidikan keluarga menurut Islam adalah metode keteladanan, metode kisah, metode kasih sayang, metode dengan memberikan ganjaran, metode nasehat, metode dialog, metode pembiasaan. 


\section{DAFTAR PUSTAKA}

Adler, Mortiner, J. Philosqfi of Education, Chicago : Part I University of Chicago, Press, 1962.

Attas, Syed Naquib, al. Konsep Pendidikan Islam, terj. Haidar Bagir,Bandung: Mizan, 1986.

Al-Bukhari, al. Sahih Al-Bukhari, Al-Miyallod, as-salis al-juz as sadis, Istambul: Dar al-Fikr, tt.

Al-Ati, Hammudah, Abd. Al. Keluarga Muslim, Surabaya: Bina Ilmu , 1984.

Al-Qattan, Manna, Khalil, al. Studi Ilmu-Ilmu Al-Qur'an, Jakarta: Litera Antar Nusa, 2000.

Al-Ahwani, Ahmad Fuad. At-Tarbiyah fil Islam, Cairo: Dar Al-Ma'arif, 1977.

Noor, Hery Aly. Ilmu Pendidikan Islam, Jakarta: Logos, 1989.

Al-Adawy, Muhammad, Ahmad. Miftahul Khitabah wal Wa'zhi. Edisi terj. Surabaya: Duta Ilmu, 1995.

Al-Halwani, Aba Firdaus. Melahirkan Anak Saleh, Yogyakarta: Mitra Pustaka, 1996.

An-Nawawi, Imam Yahya, bin Syarifuddin. Matan Arbain An-Nawawi. Surabaya : Ahmad Said bin Nabhan wa auladih, 676.

An-Nahlawi, Abdurrahman. Ushul At-Tarbiyah al-lslamiyah al-wa asalibuha fi al -Bayt wa al-Madrasah wa al- Mujtama'a. Damaskus: Dar Al-Fikri, 1979.

Arifin, Muzayin. Filsafat Pendidikan Islam, Jakarta: Bumi Aksara, 1994.

Ar-Rifa'i, Muhammad Nasib. Taisiru al-Aliyyul Qadir Li Ikhtishari Tafsir Ibnu Katsir jilid 1,2. Riyad: Maktabah Ma'arif, 1989.

Chirzin, Muhammad. Permata Al-Qur'an. Yogyakarta: Qirtas, 2003. 
Syaiful Anam : Pendidikan Pesantren Sebagai Model Yang Ideal Dalam Pendidikan Islam

Chaplin, J. P. Dictionary of Psycology. New York: Dill Publishing Co. INC, 1973.

Dahlan, Aisyah. Membina Rumah Tangga Bahagia dan Peranan Rumah Tangga Jakarta: Yamunu, 1989.

Depdikbud. Kamus Besar Bahasa Indonesia. Jakarta: Balai Pustaka,1989.

Dep. Agama RI. Al-Qur'an dan Terjemahnya. Jakarta: Yayasan Penyelenggara Penterjemah Al-Qur'an, 1999.

Al-Qur'an dan Tafsirnya. Jakarta: 1985.

Eshleman, J. R. The Family: An-Antroduction. Boston: Allyn And Bacon Icn, 1978.

Gordon Thomas. Menjadi Orang Tua Efektif, Jakarta: Gramedia,1984.

Hasanuddin, Hukum Dakwah. Jakarta: Pedoman Ilmu Jaya, 1986.

Hurlock, Elizabeth. Perkembangan Anak. Jakarta: Erlangga, 1995.

Herman, Horn. Idealistic Philosophy of Education, Chicago: Universiry of Press, 1962.

Hasymi, A. Dustur Dakwah Menurut Al-Qur'an. Jakarta: Bulan Bintang, 1974.

Halim, M, Nipan, Abdul. Anak Saleh Dambaan Keluarga. Yogyakarta: Mitra Pustaka, 2001.

Horton, Paul, B. dan Huut, Chester. Sociology. (terj.), Jakarta: Erlangga, 1987.

Idris, Zahara. Dasar-Dasar Pendidikan, Jakarta: Angkasa Raya, 1984.

Jamali, Muhammad Fadhil al. Al-Falsafah al-Tarbiyyah fi al-Qur'an. Tunis: Dar Al-Kitab al-Jadid, 1966.

Langgulung, Hasan. Manusia dan Pendidikan Suatu Analisis Psikologi dan Pendidikan. Jakarta: Pustaka Al-Husna, 1986. 
Munawir, Ahmad, Warson. Kamus Al-Munawwir. Yogyakarta: UPBIK Pondok Pesantren Krapyak, 1984.

Masbuhin, Imam. Si Kancil Yang Cerdik Yogyakarta: Mitra Pustaka, 2002.

Makluf, Lois, Al-Munjid fi al-Lughah wa 'alam. Beirut: Dar Al-Fikri, 1989.

Maclver, R.M, and, Page, Ch, H. Society, A. Texbook of Sociology. New York: Farrar and Reinhart, Inc. Publ, 1971.

Mundziri, Al-Hafizh, 'Abdul 'Azhim bin 'Abdul Qawi, Zakiyuddin, al. Mukhtashar Shahih Muslim. Riyad: Dar Ibni Khuzaimah, 1994.

Purwanto, M, Ngalim. Imu Pendidikan Teoritis dan Praktis. Bandung: PT Remaja Rosdakarya, 1995.

Quthub, Sayyid, Tafsir Fi Zilalil Qur'an.

Sabur, Alex. Anak Masa Depan. Bandung: Angkasa, 1986.

Shihab, Quraish. Tafsir Al-Mishbah juz 14, Jakarta: Lintera Hati, 2003.

Soekanto, Soejono. Sosiologi Suatu Pengantar. Jakarta: Rajawali, 1992.

Sarhani, Munir Al-Mursi. Fi Ijtima'iyyah al-Tarbiyah. Mesir: Maktabah al-Injilu al-Misriyah, 1978.

Syalabi, Ahmad. Tarikhu at-Tarbiyah al-Islamiyah (terj.) Muhtar Yahya. Jakarta: Bulan Bintang, 1973.

Syamsuddin. Pendidikan Kelamin Dalam Islam. Solo: Ramadani, 1985.

Suparta, Munzir. (ed). Metode Dakwah. Jakarta: Rahma Semesta, 2003.

Tafsir, Ahmad. Metodik Khusus Pendidikan Islam, Bandung: Remaja Rosdakarya, 1995.

Pendidikan Agama Dalam Keluarga. Bandung : PT Remaja Rosdakarya, 1995. 
Syaiful Anam : Pendidikan Pesantren Sebagai Model Yang Ideal Dalam Pendidikan Islam

Tim Dosen FIP IKIP Malang, Pengantar Dasar-Dasar Kependidikan. Surabaya: Usaha Nasional, 1981.

Ulwan, Abdullah, Nasih. Tarbjyah al-Aulad fi al-lslam, Beirut: Dar alSalam, 1993.

Uhbiyati, Nur. Ilmu Pendidikan Islam, Jakarta: Bumi Aksara, 1998.

Utsaimin, Muhammad bin Shalih, al. Dasar-dasar Penafsiran AlQur'an, terj. Semarang: Dina Utama, t.th.

Vembiarto. Sosiologi Pendidikan. Jakarta: Grasindo, 1993.

Yunus, Mahmud. Kamus Arab-Indonesia. Jakarta: Penerbit PT Hidakarya Agung, 1989.

Zuhdi, Masyfuk. Islam dan Keluarga Berencana di Indonesia, Surabaya: PT Bina Ilmu, 1982. 